\title{
Blood-Based Treatments for Severe Dry Eye Disease: The Need of a Consensus
}

\author{
Federico Bernabei ${ }^{1}$, Matilde Roda ${ }^{1}$, Marina Buzzi ${ }^{2}$, Marco Pellegrini ${ }^{1}$, \\ Giuseppe Giannaccare ${ }^{3}$ (D) and Piera Versura ${ }^{1, *(D)}$ \\ 1 Ophthalmology Unit, Department of Experimental, Diagnostic and Specialty Medicine (DIMES), Alma \\ Mater Studiorum University of Bologna, S.Orsola-Malpighi Teaching Hospital, 40138 Bologna, Italy; \\ federico.bernabei89@gmail.com (F.B.); matilde.roda@hotmail.com (M.R.); marco.pellegrini@hotmail.it (M.P.) \\ 2 Emilia Romagna Cord Blood Bank-Transfusion Service, S.Orsola-Malpighi Teaching Hospital, 40138 Bologna, \\ Italy; marina.buzzi@aosp.bo.it \\ 3 Department of Ophthalmology, University Magna Graecia of Catanzaro, 88100 Catanzaro, Italy; \\ giuseppe.giannaccare@unicz.it \\ * Correspondence: piera.versura@unibo.it; Tel.: +39-051-2142850; Fax: +39-051-6362846
}

Received: 12 August 2019; Accepted: 12 September 2019; Published: 17 September 2019

\begin{abstract}
The use of blood-based eye drops as therapy for various diseases of the ocular surface has become increasingly popular in ophthalmic practice during recent years. The rationale for their use is based on the promotion of cellular proliferation and migration thanks to the supply of metabolically active substances, in particular growth factors. Blood-derived eye drops have been used for the treatment of several ocular surface disorders, such as dry eye disease, corneal ulcer, persistent epithelial defect, neurotrophic keratitis, ocular surface burn, recurrent corneal erosion, and limbal stem-cell deficiency. Both autologous (from patients themselves) and heterologous (from adult donors or from cord blood sampled at birth)-derived products exist, and each source has specific pros and cons. Despite an extensive literature, several issues are still under debate and the aim of this manuscript is to review the indications, preparation methods and storage, characterization of content, rationale for clinical outcomes, patient stratification, length of treatment, and rationale for repeated treatments at disease relapse. A rationale based on a " $5 \mathrm{Ws}$ and $2 \mathrm{Hs}$ " protocol is proposed as a way of thinking, with the attempt to clarify Who, Why, When, Where, What, and How to use these treatment options.
\end{abstract}

Keywords: dry eye; ocular surface disease; autologous serum; allogenic serum; cord blood serum; platelet-derived eye drops

\section{Introduction}

Dry Eye Disease (DED) is "a multifactorial disease of the ocular surface characterized by a loss of homeostasis of the tear film and accompanied by ocular symptoms, in which tear film instability and hyperosmolarity, ocular surface inflammation and damage, and neurosensory abnormalities play etiological roles" [1]. DED is common in the general population, increasing with age [2], and is one of the most frequent occurrences in daily practice [3], with a substantial impact on the individual's quality of life [4]. Different modalities of treatment are available, with a proposed management algorithm based on a sequence of treatments according to the stage of disease [5]. The prescription of blood-derived products is recommended for the treatment of DED patients at stage 3 out of 4 .

The usefulness of treatment with eye drops prepared from autologous blood was first described in patients with chemical burns in the 1970s [6] and, ten years later, in patients affected by DED related to Sjögren's syndrome [7], becoming popular thereafter and increasingly introduced in ophthalmic 
practice with other blood-derived products. These consist of eye drops derived either from patients' own peripheral blood (autologous source) or from donors (allogeneic source-adult or umbilical cord blood) and prepared in the form of serum, platelet-rich plasma (PRP), plasma rich in growth factors (PRGF), and platelet lysate (PL) [8,9].

Blood-derived eye drops contain different biochemical constituents that act more closely to natural tears as compared to more conventional therapies [10,11], and the evidence of their effect on growth and proliferation of corneal epithelial cells has been investigated by in vitro and in vivo studies [12-14]. An increasing number of peer-reviewed papers have been published over the last fifteen years, showing the expanded indication for treatment, including mainly DED, persistent epithelial defect (PED), ocular graft-versus-host disease (oGVHD), recurrent corneal erosion (RCE), neurotrophic keratitis (NK), and limbal stem-cell deficiency (LSTD). Despite this extensive literature, there are still several issues under debate related both to the lack of a standardised protocol for preparation and storage and to the absence of consensus on the clinical strategy to achieve the best results, in particular, the rationale for clinical outcomes, patients' stratification, length of treatment, and the rationale for repeated treatments.

The aim of this manuscript is to review the indications, preparation methods, and clinical efficacy of blood-derived products used in ophthalmological practice, with a particular focus on unmet needs, current challenges, and future directions in clinical practice.

\section{The Rationale for Use of Blood-Derived Eye Drops}

The "Ocular Surface System" includes the epithelia of cornea and conjunctiva, the limbus (junctional zone in between), the lachrymal and meibomian glands, the tear film, the eyelids, and the nasolacrimal duct. All components are functionally integrated and linked by the integrity of the corneal epithelium; by innervation; and by the endocrine, vascular, and immune systems [15].

The cornea is a transparent avascular tissue, accounting for approximately two-thirds of overall refractive power, with a metabolism strictly dependent upon diffusion of oxygen and nutrients from the tear film anteriorly and the aqueous humour posteriorly. The integrity of the corneal epithelium is enabled by self-renewing stem cells, located in the limbus at the Palisades of Vogt, which persists throughout its lifetime. The activity of corneal epithelial stem cells (CSCEs) is finely regulated by the surrounding niche. Moreover, different factors contained in the tear film are regulated by paracrine/autocrine pathways to allow maintenance of fundamental functions, such as cellular replacement and wound healing [16].

An increasing interest in the application of human-blood-derived products such as eye drops for DED arose over the last years. Serum is the most common blood product used as eye drops, which is obtained by the physiological clotting process of blood collected without an anticoagulant. The therapeutic benefits of blood-derived serum eye drops (SED) may be explained by a composition similar to that of tears [17-19]. SED contains carbohydrates, lipids, and various electrolytes like tears, a ten-fold higher total concentration of protein, and a mixture of epitheliotrophic growth factors $[20,21]$ released by platelet alpha-granules degranulation that occurs during clotting [22].

Different types of growth factors (GFs) such as epidermal growth factor (EGF), fibroblast growth factor (FGF), transforming growth factor-beta (TGF- $\beta$ ), nerve growth factor (NGF), platelet-derived growth factor (PDGF), and insulin-like growth factor (IGF) and their receptors expressed in corneal epithelial cells, keratocytes, endothelial cells, and CSCEs stimulate turnover and proliferation of corneal cells and play a main role in maintaining ocular surface integrity $[23,24]$. To discuss the respective roles of these GFs is beyond the purpose of this manuscript, and readers are referred to reviews on this issue $[25,26]$. Finally, a reflection should be made on the continuous supply of such growth factors to the surface and, in particular, to the CSCEs which can undergo overstimulation, as it can be suggested by in vitro experiments. For instance, EGF increases proliferation of human corneal epithelial cells in a dose-dependent manner at concentrations greater than $0.1 \mathrm{ng} / \mathrm{mL}$, but at concentrations exceeding $10 \mathrm{ng} / \mathrm{mL}$, the cellular proliferation is reduced [23,27]. 
Therapeutic constituents of blood can be prepared by centrifugation, filtration, and freezing, all procedures which can influence the quality of the final product, also in terms of GF content. As the main focus is nowadays on using the specific component that is clinically indicated, processing procedures should be detailed and harmonized with an attempt to provide standardized blood products as the best of the existing options. For now, processing procedures are published and annually revised under the supervision of the European Directorate for the Quality of Medicines and HealthCare (EDQM; downloaded freely from https://www.edqm.eu/en/blood-guide) in the European Union. In the United States, blood and blood products are under the surveillance of the Food and Drug Administration (FDA; https://www.fda.gov/vaccines-blood-biologics/blood-blood-products). In Italy, according to the current legislation, recommendations for non-transfusional use of blood products is published by the Italian Society for Transfusion Medicine (SIMTI) [28].

\section{Literature Review}

\subsection{Search Strategy}

We searched PubMed, Embase, Web of Science, Ovid, Cochrane Database, and Scopus databases for original articles published up to 31 May 2019, using the keywords (all languages)("Clinical trial*" OR "autologous serum" ${ }^{*}$ OR "allogenic*" OR "cord blood*" OR "umbilical blood" OR "PRP") AND ("keratopathy" OR "dry eye" OR "neurotrophic keratitis" OR "corneal ulcer" OR "epithelial defect") without any limitation. Moreover, reference lists of retrieved studies were manually scanned for all relevant additional studies and review articles. The searches were conducted by 3 independent investigators (F.B., M.P., and M.R.). Any discrepancies were resolved by discussion or by input from another reviewer (P.V.).

\subsection{Study Selection}

After removing duplicates, 2 authors (F.B. and P.V.) individually screened titles and abstracts of all identified citations. The full text of citations deemed as potentially eligible were obtained and individually screened for eligibility, and any disagreement was discussed with all authors.

\subsection{Eligibility Criteria}

The articles were considered eligible if the studies met the following inclusion criteria: (1) study type: randomized controlled trial (RCT), retrospective; (2) population: patients having DED of any etiology, NK, PED, and RCE. Exclusion criteria were as follows: (1) lack of clinical data reporting; (2) types of publications other than original articles (e.g., abstracts from congresses, letters to editors, correspondence, reviews, duplicates, and full texts without raw data available for retrieval).

\subsection{Data Extraction}

Three reviewers (F.B., M.R., and M.P.) independently extracted the following data from each included publication: first author name, year of publication, design of the study, condition treated, inclusion criteria, number of patients and control subjects (if applicable), control arm product, solvent composition and dilution of the blood-based product, posology and duration of treatment, main outcomes, results, and retreatment parameters (rationale, cycles, time interval of treatment suspension, and total duration of treatment).

Studies with data reported in figures or with missing data were excluded. In case of disagreement among the 2 reviewers, full texts were revisited and agreed on by discussion.

\subsection{Quality Assessment}

All selected studies were graded according to the modified American Academy of Ophthalmology Preferred Practices guidelines [29] as follows. Level 1: Evidence obtained from at least one properly conducted, well-designed, randomized, controlled trial or evidence from well-designed studies 
applying rigorous statistical approaches. Level 2: Evidence obtained from one of the following: a well-designed controlled trial without randomization; a well-designed cohort or case-control analytic study, preferably from one or more center; or a well-designed study accessible to more rigorous statistical analysis. Level 3: Evidence obtained from one of the following: descriptive studies, case reports, reports of expert committees, and expert opinion.

\section{Autologous Serum Eye Drops}

Serum is the component remaining after clotting of whole blood, and it contains many of the factors present in tears. Autologous SED (auto-SED) is obtained from patients' own peripheral blood serum. Production methods including clotting time, centrifugation parameters, dilution, storage time, and temperature were shown to determine quality and characteristics of the final dispensed product, but no consensus on technical details for the preparation of auto-SED have been established so far. Hence, the formulation and dilution factor of SED for DED treatment largely rely on the experience of single blood centers according to national or regional blood establishments, as was discovered in a recent survey conducted by the Biomedical Excellence for Safer Transfusion (BEST) Collaborative on methods used at international levels to prepare SED [30].

The several studies reviewed followed, with light differences, the basic protocol proposed by Liu [31] and others. Briefly, 50-100 mL of whole blood is taken from the patient and is left for $2 \mathrm{~h}$ at room temperature until complete clotting is reached. Then, the blood is centrifuged at $3000 \mathrm{~g}$ for $15 \mathrm{~min}$ to completely separate serum from solid constituents. Next, balanced salt solution (BSS) or isotonic saline solution is added to the supernatant until the desired concentration is reached. Allo-SED has to be stored at $-20^{\circ} \mathrm{C}$ for a maximum of 3 months, and it must be kept away from light to avoid vitamin A degradation.

\subsection{Pending Issues}

\subsubsection{Dilution}

The BEST survey reported that almost half of the centers dilute serum before dispensing in order to reduce to a physiologic concentration the levels of potentially anti-proliferative factors, such as TGF- $\beta$, which has shown to slow down corneal healing and to facilitate corneal stromal fibrosis and opacity in vitro $[23,32]$. Indeed, it has been shown that TGF- $\beta$ plays a main role in the development of mature myofibroblasts during corneal healing after injury, producing a disorganized extracellular matrix in the stroma that results in loss of transparency [33]. Nevertheless, serum dilution leads to decreased levels of trophic factors, potentially limiting its beneficial effects. A recent Cochrane, which reviewed four clinical trials on auto-SED, reported the use of $20 \%$ dilution in all the studies [34]. Several studies investigated the use of higher concentrations (50 to 100\%), reporting an excellent clinical efficacy and no adverse effect [35-38]. Moreover, other authors proposed to dilute SED to 20\% in a sodium hyaluronate solution to improve retention time and to decrease the frequency of administration and reported good results. [39]. Given these evidences, it cannot be excluded that formulation may have to be adjusted to the treated disease or to its extent.

\subsubsection{Storage}

Significant differences were reported in terms of recommended maximal storage time for serum drops, in part, due to internationally varying laws/regulations. It has been reported that several serum GFs are temperature and time resistant but substance $\mathrm{P}$ and calcitonin gene-related peptides

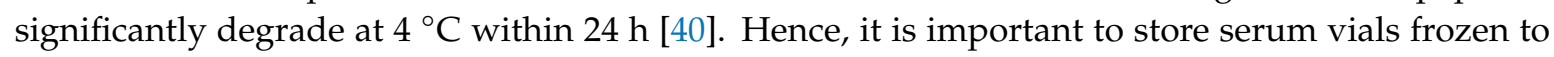
preserve the activity of epitheliotrophic factors [41], which have been shown to be maintained until a prolonged storage of 6 months at $-20^{\circ} \mathrm{C}$ [42]. 


\subsubsection{Safety}

Exposure to contaminated SED should be avoided, especially in DED patients who have a higher risk of developing infections because of their diseased surface. SED are prepared based on the guidelines for good manufacturing practice (GMP) [43], generally in open systems with a remote but still potential risk of contamination during the manufacturing process. Very few cases of adverse events related to contamination have been reported in the literature (reviewed in Reference [44]). To improve safety, sealed manufacturing systems (which package the eye drops into vials or long lengths of tubing, which are then heat-sealed to produce single-use devices) have been proposed in the market [45-47], but financial and logistic barriers are still unaffordable in many centers [48].

\subsection{Clinical Results}

Six RCTs investigated the efficacy of auto-SED for the treatment of severe DED (Table 1) [49-54]. Improvement of symptoms and signs (tear breakup time (TBUT), corneal staining, and conjunctival impression cytology) was reported in severe DED patients after therapy with auto-SED and tear substitutes with [50,51] or without [49] significant differences between the groups. In a cross-over study, severe DED patients were randomized to receive 3 months of treatment with auto-SED $50 \%$ and 3 months with conventional therapy, and viceversa; symptoms and impression cytology of conjunctival epithelial cells improved more significantly after treatment with auto-SED [50]. Two recent cross-over trials on severe DED reported a higher decrease of symptoms score in the auto-SED group compared to the control group treated with tear substitutes [52,53]; nevertheless, a significant improvement of TBUT was also reported in the auto-SED group only in the study from Celebi [53]. Yilmaz et al. reported a significant magnitude of the mean improvement of symptoms and TBUT in patients with DED due to systemic isotretinoin after auto-SED therapy compared to those treated with tear substitutes [54].

Several non-randomized studies evaluated the efficacy of auto-SED in DED of different aetiologies. Ogawa et al. investigated the use of auto-SED in patients affected by oGVHD, reporting a significant improvement of symptoms, TBUT, and corneal staining [55]. Two prospective studies evaluated the use of auto-SED in patients affected by primary and secondary Sjögren Syndrome (SS), with an improvement of both signs and symptoms only in patients with primary SS [56] or of only symptoms [57]. Both undiluted and diluted 20\% auto-SED seem to ameliorate DED related to SS. In particular, Cho et al. [37] treated patients with SS DED (not distinguishing between primary and secondary), non-SS DED, and PED with undiluted auto-SED, 50\% auto-SED in saline, or 50\% auto-SED in sodium hyaluronate, reporting different results for different aetiologies. Jirsova et al. [58] treated DED associated with primary Sjögren, secondary Sjögren, sarcoidosis, and unknown aetiologies with 20\% auto-SED in saline and reported significant improvements of clinical findings and symptoms occurring in $77 \%$ and $63 \%$ of eyes, respectively, but they did not stratify patients according to aetiology.

López-Garcia et al. [39] treated SS DED (not distinguishing between primary and secondary) with $20 \%$ auto-SED in saline or 20\% auto-SED in sodium hyaluronate and compared the efficacy of two different dilution vehicles for auto-SED delivery. They demonstrated that both sodium hyaluronate and saline determine a significant improvement of tear-film stability, corneal staining, TBUT, and symptoms but without significant differences.

The potential efficacy of auto-SED treatment was investigated also in other ocular surface diseases, in particular NK, PED related to different causes (i.e., post refractive surgery, post perforating keratoplasty, and other ocular surgery), RCE, and LSCD (Limbal Stem Cell Deficiency) [59-65].

In a retrospective case series, auto-SED treatment for NK refractory to conventional therapy lead to complete healing in $100 \%$ of patients and to an improvement of corneal sensitivity in $64 \%$ of patients [59]. A large prospective study evaluated undiluted auto-SED treatment for PED due to different types of ocular surgery and reported a complete corneal healing in more than $90 \%$ of patients on an average of 4 days [63]. In a case-controlled study on pterygium surgery, auto-SED promoted a faster corneal re-epithelialization as compared to tear substitutes [64]. 
A randomized trial compared auto-SED treatment with tear substitutes after laser in situ keratomileusis (LASIK) and reported an improvement in TBUT and rose bengal staining in the auto-SED group, with no difference in symptom scores between groups [60].

In a large case-controlled study that compared auto-SED with tear substitutes after PK, patients who received auto-SED showed a significant improvement of corneal re-epithelialization time. Moreover, the efficacy of auto-SED was reported even in difficult cases such as larger-diameter grafts and diabetic patients [65].

Schulze et al. compared autologous serum therapy with hyaluronic tears in diabetic patients undergoing pars plana vitrectomy who received corneal abrasion for better intraoperative visualization [61]. Patients treated with auto-SED showed a significant improvement of the closure of corneal epithelium compared to the control group [61].

A prospective study investigated auto-SED treatment in patient RCE refractory to standard therapy. After auto-SED treatment, complete corneal healing was reported in $100 \%$ of cases, and in $85 \%$ of cases, no relapse occurred during the following 12 months. [62]. Auto-SED treatment in 13 patients affected by LSCD due to aniridia lead to an improvement of tear stability, corneal epithelialization, and symptoms [66].

Although the encouraging results reported in the RCTs on the efficacy of auto-SED therapy for severe DED, a Cochrane meta-analysis published in 2013 and based on 4 auto-SED RCTs showed an overall inconsistency in patient's reported symptoms and lack of effect based on objective clinical measures, concluding that high-quality RCTs are warranted to assess the benefits of this treatment in DED [34]. The 21 studies on auto-SED included in the present review had levels of evidence 1 (9 studies) or 2 (11 studies) and only one study had level 3, with only 11 studies analyzing auto-SED with a comparator, generally unspecified tear substitutes. In agreement with the Cochrane report, however, the inconsistency of measures and standardized preparation prevent a conclusive statement on auto-SED efficacy as compared to conventional treatments.

\section{Allogeneic Adult Peripheral Blood Serum Eye Drops}

The rationale for the use of SED prepared from donor sources is now driven by the assumption of negative effects caused by serum-derived autoantibodies or pro-inflammatory cytokines that would be deliberately applied to the ocular surface in patients with important comorbidities. Peripheral blood from adult donors and cord blood sampled from umbilical veins at birth are now eligible candidates for allogeneic sources. Although SED of autologous origin is still the most manufactured product, an increasing number of centers worldwide is now producing SED from allogeneic blood donors [67-75]. When the SED are from allogeneic origins, procedures must be undertaken to match all blood groups to ensure hemato-immunological $\mathrm{ABO}$ antigen matching between donors and recipients. One option could be to prepare SED from AB group donors to hold a single blood group source, but the limited prevalence of the $\mathrm{AB}$ group in the Caucasian population may limit the availability of this source. 
Table 1. Summary of studies related to Auto-SED. Legend: Auto-SED = Autologous serum eye drops; CIC = Conjunctival impression cytology; $\mathrm{CMC}=$ Carboxymethylcellulose; $\mathrm{d}=$ day; DED = Dry eye disease; FS = Fluorescein staining; GVHD = Graft versus host disease; I = interventional; ISS = Isotonic Saline Solution; LASIK = Laser assisted in situ keratomileusis; M = Month; NaHy = Sodium hyalutonate; NK = Neurotrophic keratitis; OSDI = Ocular Surface Disease Index; P = Prospective; PED = Persistent epithelial defects; PK = Penetrating Keratoplasty; RCT = randomized controlled trial; RBS = Rose Bengal staining; SS = Sjogren's syndrome; LSCD = Limbal stem cell deficiency; ST = Schirmer test; TBUT = Tear Break Up Time; wks = weeks .

\begin{tabular}{|c|c|c|c|c|c|c|c|c|c|c|c|c|c|}
\hline $\begin{array}{l}\text { Study First } \\
\text { Name, Year }\end{array}$ & $\begin{array}{c}\text { Evidence } \\
\text { Level }\end{array}$ & Design & Condition & Inclusion Criteria & $\begin{array}{l}\text { Patients } \\
(n)\end{array}$ & $\begin{array}{c}\text { Controls } \\
(n)\end{array}$ & Control arm & Solvent & Dilution & Posology & $\begin{array}{c}\text { Duration of } \\
\text { Treatment }\end{array}$ & Main Outcomes & Results \\
\hline $\begin{array}{l}\text { Tananuvat } \\
2001[49]\end{array}$ & 2 & RCT & DED & $\begin{array}{l}\text { Refractory to treatment } \\
\text { (tear substitute, punctum } \\
\text { plug) }\end{array}$ & 12 & $\begin{array}{l}\text { Fellow } \\
\text { eye }\end{array}$ & Saline solution & ISS & $20 \%$ & $6 \times / d$ & $2 \mathrm{Ms}$ & $\begin{array}{l}\text { Subjective } \\
\text { symptoms, FS, } \\
\text { RBS, and CIC }\end{array}$ & $\begin{array}{c}\text { No significant } \\
\text { improvement of } \\
\text { symptoms and signs } \\
\text { between the two groups }\end{array}$ \\
\hline $\begin{array}{c}\text { Ogawa } 2003 \\
\text { [55] }\end{array}$ & 2 & $\mathrm{P}, \mathrm{I}$ & $\begin{array}{c}\text { DED } \\
\text { (GVHD) }\end{array}$ & $\begin{array}{l}\text { Refractory to treatment } \\
\text { (tear substitute) }\end{array}$ & 14 & I & 1 & ISS & $20 \%$ & $10 \times / \mathrm{d}$ & $4-41 \mathrm{Ms}$ & $\begin{array}{c}\text { Subjective } \\
\text { symptoms, FS, } \\
\text { RBS, TBUT, and } \\
\text { Schirmer test } \\
\end{array}$ & $\begin{array}{l}\text { Improvement of } \\
\text { symptoms, TBUT, RBS, } \\
\text { and FS }\end{array}$ \\
\hline $\begin{array}{c}\text { Matsumoto } \\
2004 \text { [59] }\end{array}$ & 3 & $\begin{array}{l}\text { Retrospective, } \\
\text { non-comparative } \\
\text { case series }\end{array}$ & e NK & $\begin{array}{c}\text { Refractory to treatment } \\
\text { (therapeutic contact lenses, } \\
\text { tear substitute, and sodium } \\
\text { hyaluronate) }\end{array}$ & 11 & 1 & I & ISS & $20 \%$ & $5-10 \times / \mathrm{d}$ & Up to $36 \mathrm{Ms}$ & $\begin{array}{c}\text { Changes in } \\
\text { corneal disease } \\
\text { state, corneal } \\
\text { sensitivity, and } \\
\text { BCVA }\end{array}$ & $\begin{array}{l}100 \% \text { healing; } 64 \% \\
\text { increase of corneal } \\
\text { sensitivity }\end{array}$ \\
\hline $\begin{array}{c}\text { Noble } 2004 \\
\text { [50] }\end{array}$ & 1 & $\begin{array}{l}\text { RCT, Cross } \\
\text { over }\end{array}$ & DED & $\begin{array}{l}\text { Epitheliopathy with } \\
\text { corneal/conjunctival RBS, } \\
\text { ST }<5 \mathrm{~mm} / 5 \mathrm{~min} \text { and } \\
\text { punctal occlusion }\end{array}$ & $8+8$ & $8+8$ & $\begin{array}{c}\text { Conventional } \\
\text { treatment }\end{array}$ & ISS & $50 \%$ & $\begin{array}{l}\text { As previous } \\
\text { therapy }\end{array}$ & $3 \mathrm{Ms}+3 \mathrm{Ms}$ & $\begin{array}{c}\text { Subjective } \\
\text { symptoms, TBUT, } \\
\text { ST, FS, clearance } \\
\text { test, and CIC }\end{array}$ & $\begin{array}{l}\text { Improvement of } \\
\text { symptoms and CIC } \\
\text { after Allo-SED }\end{array}$ \\
\hline $\begin{array}{l}\text { Kojima } 2005 \\
{[51]}\end{array}$ & 1 & RCT & DED & $\begin{array}{c}\text { DED symptoms, positive FS } \\
\text { or RBS, } \mathrm{ST}<5 \mathrm{~mm} / 5 \mathrm{~min} \text { or } \\
\text { TBUT }<5 \mathrm{~s}\end{array}$ & 10 & 10 & $\begin{array}{l}\text { Preservative-free } \\
\text { tear substitute }\end{array}$ & ISS & $20 \%$ & $6 \times / \mathrm{d}$ & $2 \mathrm{wks}$ & $\begin{array}{c}\text { Subjective } \\
\text { symptoms, FS, } \\
\text { RBS, TBUT, and ST }\end{array}$ & $\begin{array}{l}\text { Improvement of } \\
\text { symptoms, TBUT, RBS, } \\
\text { and FS in Allo-SED } \\
\text { group }\end{array}$ \\
\hline $\begin{array}{l}\text { Noda-Tsuruya } \\
2006 \text { [60] }\end{array}$ & 1 & RCT & Post-LASIK & $\begin{array}{l}\text { Patients who received } \\
\text { LASIK }\end{array}$ & 12 & 15 & Tear substitute & ISS & $20 \%$ & $5 \times / \mathrm{d}$ & 1 week-6 $\mathrm{M}$ & $\begin{array}{c}\text { Subjective } \\
\text { symptoms, FS, } \\
\text { RBS, TBUT, and ST }\end{array}$ & $\begin{array}{l}\text { Improvement of TBUT, } \\
\text { FS, and RBS. No change } \\
\text { in symptoms }\end{array}$ \\
\hline $\begin{array}{c}\text { Schulze } 2006 \\
\text { [61] }\end{array}$ & 2 & RCT & $\begin{array}{l}\text { Corneal } \\
\text { Epithelial } \\
\text { Abrasions in } \\
\text { Diabetic } \\
\text { Patients }\end{array}$ & $\begin{array}{c}\text { Diabetic patients } \\
\text { undergoing pars plana } \\
\text { vitrectomy who received } \\
\text { corneal abrasion for better } \\
\text { intraoperative visualization }\end{array}$ & 13 & 10 & $\mathrm{NaHy}$ & ISS & $50 \%$ & Every hour & $\begin{array}{l}\text { Until } \\
\text { epithelial } \\
\text { healing }\end{array}$ & Size of abrasion & $\begin{array}{l}\text { Faster closure of corneal } \\
\text { epithelial wounds }\end{array}$ \\
\hline $\begin{array}{l}\text { López-Garcia } \\
2008 \text { [66] }\end{array}$ & 2 & $P, I$ & LSCD & Aniridic keratopathy & 13 & I & I & $\begin{array}{l}\text { Isotonic } \\
\text { saline } \\
\text { solution }\end{array}$ & $20 \%$ & $8 \times / \mathrm{d}$ & $2 \mathrm{Ms}$ & $\begin{array}{c}\text { CIC, TBUT, ST, } \\
\text { and tear meniscus } \\
\text { level }\end{array}$ & $\begin{array}{c}\text { Improvement of } \\
\text { symptoms } \\
\text { epithelialization, and ST }\end{array}$ \\
\hline
\end{tabular}


Table 1. Cont.

\begin{tabular}{|c|c|c|c|c|c|c|c|c|c|c|c|c|c|}
\hline $\begin{array}{l}\text { Study First } \\
\text { Name, Year }\end{array}$ & $\begin{array}{c}\text { Evidence } \\
\text { Level }\end{array}$ & Design & Condition & Inclusion Criteria & $\begin{array}{c}\text { Patients } \\
(n)\end{array}$ & $\begin{array}{c}\text { Controls } \\
(n)\end{array}$ & Control arm & Solvent I & Dilution & Posology & $\begin{array}{c}\text { Duration of } \\
\text { Treatment }\end{array}$ & Main Outcomes & Results \\
\hline $\begin{array}{l}\text { Ziakas } 2010 \\
{[62]}\end{array}$ & 2 & $\mathrm{P}, \mathrm{I}$ & $\begin{array}{l}\text { Recurrent } \\
\text { Corneal } \\
\text { Erosion }\end{array}$ & $\begin{array}{l}\text { Refractory to treatment and } \\
\text { history of at least three } \\
\text { relapses }\end{array}$ & 33 & 1 & 1 & ISS & $20 \%$ & $\begin{array}{c}6 \times / \mathrm{d} \text { for } \\
3 \mathrm{Ms} \text {, then } \\
3 \times / \mathrm{d} \text { for } \\
3 \mathrm{Ms}\end{array}$ & $6 \mathrm{Ms}$ & $\begin{array}{l}\text { Subjective } \\
\text { symptomsand } \\
\text { recurrence }\end{array}$ & $\begin{array}{l}85 \% \text { healing with no } \\
\text { recurrences over the } \\
\text { whole follow-up period }\end{array}$ \\
\hline Chen 2010 [65] & 1 & $P, I$ & Post PK & Patients who received PK & 82 & 83 & Tear substitute & $\begin{array}{c}\text { Tear } \\
\text { substitute }\end{array}$ & $20 \%$ & $8 \times / \mathrm{d}$ & $3 \mathrm{~d}-2$ wks & $\begin{array}{c}\text { Corneal epithelial } \\
\text { healing }\end{array}$ & $\begin{array}{l}\text { Improvement of healing } \\
\text { time }\end{array}$ \\
\hline $\begin{array}{l}\text { Urzua } 2012 \\
\quad[52]\end{array}$ & 1 & $\begin{array}{l}\text { RCT, Cross } \\
\text { over }\end{array}$ & DED (NSS) & $\begin{array}{c}\text { DED symptoms score more } \\
\text { than } 40 \text { (OSDI } \\
\text { questionnaire), TBUT }<5 \mathrm{~s} \text {, } \\
\text { positive FS or ST }<5 \mathrm{~mm} / \\
5 \mathrm{~min} \\
\end{array}$ & $6+6$ & $6+6$ & Tear substitute & ISS & $20 \%$ & $4 \times / \mathrm{d}$ & $\begin{array}{c}2 \mathrm{wks}+ \\
2 \mathrm{wks}\end{array}$ & $\begin{array}{l}\text { Subjective } \\
\text { symptoms }\end{array}$ & $\begin{array}{l}\text { Improvement of OSDI } \\
\text { after Allo-SED }\end{array}$ \\
\hline $\begin{array}{l}\text { Lekhanont } \\
2013 \text { [63] }\end{array}$ & 2 & $P, I$ & $\begin{array}{l}\text { PED after } \\
\text { ocular } \\
\text { surgery }\end{array}$ & Refractory to treatment & 181 & 1 & 1 & $\begin{array}{l}\text { Tear } \\
\text { substitute }\end{array}$ & $100 \%$ & Every $2 \mathrm{~h}$ & $\begin{array}{l}\text { Until full } \\
\text { healing }\end{array}$ & $\begin{array}{c}\text { Rate of full } \\
\text { healing corneal } \\
\text { epithelial defect }\end{array}$ & $93 \%$ healing within $4 \mathrm{~d}$ \\
\hline Cho 2013 [37] & 2 & $P, I$ & $\begin{array}{l}\text { DED (SS and } \\
\text { NSS) PED }\end{array}$ & $\begin{array}{c}\text { DED: Symptoms, TBUT } \leq 5 \\
\text { S, ST } \leq 5 \mathrm{~mm} / 5 \mathrm{~min}, \\
\text { positive corneal FS } \\
\text { PED: Refractory to } \\
\text { treatment (tear substitute, } \\
\text { patching, and therapeutic } \\
\text { contact lenses) }\end{array}$ & 22 & $\begin{array}{l}\text { Group 2: } \\
\quad 35 \\
\text { Group 3: } \\
\quad 28\end{array}$ & I & $\begin{array}{c}\text { ISS; } \\
\text { NaHy; } \\
\text { Ceftazidime }\end{array}$ & $\begin{array}{c}100 \% \text { vs. } \\
50 \%\end{array}$ & $6 \times / \mathrm{d}$ & $3 \mathrm{Ms}$ & $\begin{array}{c}\text { Subjective } \\
\text { symptoms, TBUT, } \\
\text { ST, FS, and rate of } \\
\text { complete healing } \\
\text { of PED }\end{array}$ & $\begin{array}{l}\text { In SS and PED, } \\
\text { Allo-SED 100\% was the } \\
\text { most effective in } \\
\text { decreasing symptoms } \\
\text { and FS and in } \\
\text { accelerating healing. In } \\
\text { NSS, Allo-SED 100\% } \\
\text { and 50\% were similar in } \\
\text { reducing symptoms } \\
\text { and FS }\end{array}$ \\
\hline $\begin{array}{l}\text { Celebi } 2014 \\
\quad[53]\end{array}$ & 1 & $\begin{array}{c}\text { RCT, } \\
\text { Cross-over } \\
\text { trial }\end{array}$ & DED & Refractory to treatment & $10+10$ & $10+10$ & $\begin{array}{l}\text { Preservative-free } \\
\text { tear substitute }\end{array}$ & ISS & $20 \%$ & $4 \times / \mathrm{d}$ & $1 \mathrm{M}+1 \mathrm{M}$ & $\begin{array}{l}\text { Subjective } \\
\text { sympthoms }\end{array}$ & $\begin{array}{l}\text { Significant } \\
\text { improvement of OSDI } \\
\text { and TBUT after } \\
\text { Allo-SED. No change of } \\
\text { corneal damage and ST }\end{array}$ \\
\hline $\begin{array}{l}\text { Hussain } 2014 \\
{[38]}\end{array}$ & 2 & $\begin{array}{l}\text { Retrospective, } \\
\text { cohort study }\end{array}$ & DED & $\begin{array}{l}\text { Refractory to treatments } \\
\text { (lubrication, topical } \\
\text { corticosteroids, } \\
\text { cyclosporine } 0.05 \% \text {, and/or } \\
\text { punctal occlusion) }\end{array}$ & 63 & I & I & ISS & $50 \%$ & $4 \times / \mathrm{d}$ & $3 \mathrm{Ms}-48 \mathrm{Ms}$ & $\begin{array}{l}\text { Subjective } \\
\text { symptoms, FS, } \\
\text { TBUT, and ST }\end{array}$ & $\begin{array}{c}\text { Significant } \\
\text { improvement of TBUT, } \\
\text { FS, and symptoms }\end{array}$ \\
\hline $\begin{array}{l}\text { Lopez-Garcia } \\
\text { 2014 [39] }\end{array}$ & 1 & RCT & DED (SS) & Diagnosis of SS & $13+13$ & I & I & ISS & $20 \%$ & $3 \times / \mathrm{d}$ & $2 \mathrm{Ms}$ & $\begin{array}{l}\text { TBUT, ST, FS, RBS, } \\
\text { and CIC }\end{array}$ & $\begin{array}{c}\text { Improvement of } \\
\text { symptoms, } \\
\text { epithelialization, BUT, } \\
\text { and ST in both groups }\end{array}$ \\
\hline $\begin{array}{c}\text { Hwang } 2014 \\
{[56]}\end{array}$ & 2 & $\begin{array}{c}\text { P, I, } \\
\text { cross-sectional }\end{array}$ & DED (SS) & $\begin{array}{c}\text { ST }<5 \mathrm{~mm} / 5 \mathrm{~min} \text {, corneal } \\
\text { Staining above } 2 \text { (Oxford } \\
\text { Scale) }\end{array}$ & 34 & l & I & $\mathrm{NaHy}$ & $50 \%$ & $8 \times / \mathrm{d}$ & $4 \mathrm{wks}$ & $\begin{array}{l}\text { Subjective } \\
\text { symptoms, FS, } \\
\text { and TBUT }\end{array}$ & $\begin{array}{l}\text { Patients with primary } \\
\text { SS had improvements in } \\
\text { ocular symptoms, FS, } \\
\text { and TBUT. Patients with } \\
\text { secondary SS had no } \\
\text { improvement. }\end{array}$ \\
\hline
\end{tabular}


Table 1. Cont.

\begin{tabular}{|c|c|c|c|c|c|c|c|c|c|c|c|c|c|}
\hline $\begin{array}{l}\text { Study First } \\
\text { Name, Year }\end{array}$ & $\begin{array}{c}\text { Evidence } \\
\text { Level }\end{array}$ & Design & Condition & Inclusion Criteria & $\begin{array}{l}\text { Patients } \\
(n)\end{array}$ & $\begin{array}{c}\text { Controls } \\
(n)\end{array}$ & Control arm & Solvent & Dilution & Posology & $\begin{array}{c}\text { Duration of } \\
\text { Treatment }\end{array}$ & Main Outcomes & Results \\
\hline $\begin{array}{c}\text { Jirsova } 2014 \\
\quad[58]\end{array}$ & 2 & $P, I$ & DED & $\begin{array}{c}\mathrm{ST} \text { I }<5 \mathrm{~mm} / 5 \mathrm{~min}, \mathrm{TBUT}< \\
5 \mathrm{~s}\end{array}$ & 17 & I & I & ISS & $20 \%$ & $\begin{array}{l}\text { Open, up to } \\
12 \times / \mathrm{d}\end{array}$ & $3 \mathrm{Ms}$ & $\begin{array}{l}\text { Subjective } \\
\text { symptoms, FS, } \\
\text { CIC, and ST }\end{array}$ & $\begin{array}{c}\text { Significant } \\
\text { improvement of ST and } \\
\text { symptoms }\end{array}$ \\
\hline $\begin{array}{c}\text { Semeraro } 2016 \\
{[57]}\end{array}$ & 2 & $\begin{array}{c}\text { P, I, } \\
\text { case-control }\end{array}$ & $\mathrm{DED}(\mathrm{SS})$ & $\begin{array}{l}\text { DED symptoms, } \mathrm{ST}<5 \\
\mathrm{~mm} / \mathrm{min} \text { or TBUT }<10 \mathrm{~s}\end{array}$ & 12 & 12 & Tear substitute & ISS & $50 \%$ & $5 \times / d$ & $12 \mathrm{Ms}$ & $\begin{array}{c}\text { Tear production, } \\
\text { tear stability, and } \\
\text { FS }\end{array}$ & $\begin{array}{c}\text { Significant } \\
\text { improvement of } \\
\text { symptoms }\end{array}$ \\
\hline $\begin{array}{l}\text { Yilmatz } 2017 \\
{[54]}\end{array}$ & 1 & $\begin{array}{c}\mathrm{RCT} \\
\text { cross-over } \\
\text { trial }\end{array}$ & $\begin{array}{l}\text { DED (due to } \\
\text { isotretinoin) }\end{array}$ & $\begin{array}{l}\text { DED symptoms, TBUT }<10 \\
\mathrm{~s}, \mathrm{ST}<10 \mathrm{~mm} / \mathrm{min}\end{array}$ & 24 & 24 & $\begin{array}{l}\text { Preservative-free } \\
\text { tear substitute }\end{array}$ & ISS & $20 \%$ & Not specified & $1 \mathrm{M}+1 \mathrm{M}$ & $\begin{array}{l}\text { Subjective } \\
\text { symptoms, ST, } \\
\text { and TBUT }\end{array}$ & $\begin{array}{c}\text { Significant } \\
\text { improvement of } \\
\text { symptoms and TBUT in } \\
\text { Allo-SED group }\end{array}$ \\
\hline Sul 2018 [64] & 1 & $\begin{array}{c}\text { P, I, } \\
\text { case-control }\end{array}$ & $\begin{array}{c}\text { Post } \\
\text { Pterygium } \\
\text { excision }\end{array}$ & $\begin{array}{l}\text { Patients who received } \\
\text { Pterygium Excision }\end{array}$ & 25 & 25 & Tear substitute & CMC & $50 \%$ & $8 \times / d$ & $3-8 \mathrm{~d}$ & $\begin{array}{c}\text { Subjective } \\
\text { symptoms and } \\
\text { corneal epithelial } \\
\text { healing }\end{array}$ & $\begin{array}{l}\text { Improvement of healing } \\
\text { time and symptoms }\end{array}$ \\
\hline
\end{tabular}


The use of allogenic serum obtained from healthy donors has been introduced as a possible alternative to auto-SED in patients with inaccessible peripheral venous access or use of anticoagulant medications or coexisting systemic diseases such as coagulation factor deficiency and haematological disease. Moreover, some authors reported that peripheral serum of SS and oGVHD patients that represent two of the most common causes of severe DED might contain high concentrations of pro-inflammatory mediators potentially harmful to the ocular surface [76], although others disagree [45]. In addition, it has been shown that other diseases are associated with an altered serum composition that presents significantly decreased epitheliotrophic properties, in particular, in patients with chronic renal failure and rheumatoid arthritis $[77,78]$. Other disadvantages of auto-SED are that some people fear venipuncture and the prolonged treatment, and the frequent drawing of blood can be inconvenient in others. Cultural considerations also play some role as, in Asian cultures, the belief is held that frequent blood sampling increases weakness and susceptibility to infections [69].

Preparation methods of allogeneic SED (allo-SED) are the same as that of auto-SED. The whole blood is taken and stored at room temperature until it is clotted. Next, serum is separated by centrifugation at $3000 \mathrm{~g}$ for $15 \mathrm{~min}$, filtered, and diluted to $20 \%$ concentration [36]. Allogeneic blood donors donating blood for the production of SED should be screened for virus markers using the same procedures that are applied to donations used for transfused blood products $[30,43,79]$.

The use of allo-SED also poses some issues related to legal or ethical concerns [80], and a written informed consent is required in many legislations.

\section{Clinical Results}

Table 2 reports the list and details of the main studies related to the use of allo-SED.

Chiang et al. [69] investigated the use of allo-SED in patients affected by PED due to different causes, including penetrating keratoplasty (PK), NK, oGVHD, and exposure keratopathy, that were refractory to standard treatment. Relatives donated blood for the preparation of allo-SED that was used at a concentration of $100 \%$. Almost half of the treated patients showed complete healing within 2 weeks that was reached in $63.9 \%$ of patients within 4 weeks.

Allo-SED efficacy was evaluated also in patients with DED related to oGVHD. In particular, after four weeks of treatment with $20 \%$ allo-SED obtained from healthy donors, a significant decrease in symptoms score, tear osmolarity, corneal staining, and TBUT was noted [72]. Furthermore, another study reported a significant improvement in symptoms and ocular surface parameters in 2 oGVHD patients treated with allo-SED [70].

Harritshøj et al. evaluated the efficacy of allo-SED $20 \%$ prepared from blood of identical ABO groups in patients affected by both DED and PED [71]. They showed a significant improvement in symptoms and signs in the DED group, while no significant changes were the PED group.

A randomized, double-blind study on DED patients evaluated comparatively by confocal microscopy the effect on the corneal sub-basal nerve plexus of a one-month treatment with two allogeneic products, namely peripheral blood serum from adult donor or umbilical cord blood serum (UCBS) eye drops [81]. Overall, both treatments significantly improved corneal sub-basal nerve plexus parameters, with a superiority for UCBS drops associated with a higher increase of the corneal nerve fractal dimension global metric.

Since 2007, 39\% of all SEDs issued in New Zealand have been allogeneic [68], and a cross-over retrospective study was recently reported [74], dealing with a comparison of autologous and allo-SED in patients who served as their own controls. Results demonstrated a comparable efficacy and tolerability in both products, and most of those who changed from autologous to allo-SED reported either maintained benefits or further improvement, but a prospective randomized trial is now needed to confirm this observation. 
Table 2. Summary of studies related to Allo-SED from adult donors. Legend: Allo-SED = Allogenic serum eye drops; CMC $=$ Carboxymethylcellulose; $\mathrm{d}=$ day; $\mathrm{DED}=$ Dry eye disease; FS = Fluorescein staining; GVHD = Graft versus host disease; I = interventional; ISS = Isotonic Saline Solution; OSDI = Ocular Surface Disease Index; P = Prospective; PED = Persistent epithelial defects; ST = Schirmer test; TBUT = Tear Break Up Time; wks = weeks.

\begin{tabular}{|c|c|c|c|c|c|c|c|c|c|c|c|c|c|}
\hline $\begin{array}{l}\text { Study First } \\
\text { Name, Year }\end{array}$ & $\begin{array}{c}\text { Evidence } \\
\text { Level }\end{array}$ & Design & Condition & Inclusion Criteria & $\begin{array}{l}\text { Patients } \\
\quad(n)\end{array}$ & $\begin{array}{c}\text { Controls } \\
(n)\end{array}$ & $\begin{array}{c}\text { Control } \\
\text { Arm }\end{array}$ & Solvent & Dilution & Posology & $\begin{array}{c}\text { Duration of } \\
\text { Treatment }\end{array}$ & Main Outcomes & Results \\
\hline $\begin{array}{l}\text { Chiang } 2009 \\
{[69]}\end{array}$ & 2 & P,I & PED & $\begin{array}{l}\text { PED since }>2 \mathrm{wks} \\
\text { refractory to treatment } \\
\text { (tear substitute and } \\
\text { soft contact lenses) }\end{array}$ & 36 & I & I & I & $100 \%$ & $\begin{array}{l}\text { Every } \\
\text { hour }\end{array}$ & Variable & Healing & $\begin{array}{l}\text { Complete healing in } 42 \% \\
\text { within } 2 \text { weeks }\end{array}$ \\
\hline $\begin{array}{l}\text { Na and Kim } \\
2012[72]\end{array}$ & 2 & P,I & $\begin{array}{c}\text { DED } \\
\text { (GVHD) }\end{array}$ & $\begin{array}{c}\text { Refractory to } \\
\text { treatment }\end{array}$ & 16 & I & I & $\begin{array}{l}\text { CMC and } \\
\text { ofloxacin }\end{array}$ & $20 \%$ & $6-8 \times / d$ & $4 \mathrm{wks}$ & $\begin{array}{l}\text { Subjective symptom, } \\
\text { TBUT, ST, FS, tear } \\
\text { osmolarity, corneal } \\
\text { staining, and CIC } \\
\end{array}$ & $\begin{array}{l}\text { Improvement in OSDI, FS, } \\
\text { IC, and tear osmolarity }\end{array}$ \\
\hline $\begin{array}{l}\text { Harritshøj } \\
2014 \text { [71] }\end{array}$ & 3 & $\begin{array}{l}\text { Retrospective } \\
\text { cohort }\end{array}$ & DED, PED & $\begin{array}{c}\text { Refractory to } \\
\text { treatment }\end{array}$ & $\begin{array}{l}\text { DED } 20 \\
\text { PED } 14\end{array}$ & l & I & ISS & $20 \%$ & $6 \times / d$ & $2-4 \mathrm{wks}$ & $\begin{array}{l}\text { Subjective } \\
\text { symptoms and } \\
\text { healing }\end{array}$ & $\begin{array}{l}\text { Improvement of symptoms } \\
\text { and FS in DED group at } 4 \\
\text { wks. No Improvement in } \\
\text { PED group }\end{array}$ \\
\hline
\end{tabular}




\section{Allogeneic Umbilical Cord Blood Serum Eye Drops}

Umbilical cord blood serum is collected from mothers during both vaginal and caesarean delivery. An informed consent must be signed prior to performing the blood collection. From 10 to $20 \mathrm{~mL}$ of the umbilical cord blood is collected from the umbilical vein after delivery. The blood is clotted for $2 \mathrm{~h}$ at room temperature; after centrifugation at $3000 \mathrm{rpm}$ for $15 \mathrm{~min}$, the serum is isolated carefully under sterile conditions in a laminar air flow hood. Then, $20 \%$ concentration is reached by the dilution with BSS. The serum is aliquoted into sterile $1-\mathrm{mL}$ vials with ultraviolet light protection. Sealed eye drop vials are stored in a freezer at $-20^{\circ} \mathrm{C}$ for a maximum of 3 months, and opened bottles are kept in a refrigerator at $4{ }^{\circ} \mathrm{C}$ [46]. To avoid the transmission of blood-borne diseases, tests for HCV, HBV, HIV, syphilis, toxoplasma, and CMV have to be performed.

As for allo-SED, UCBS represents a possible therapy for patients affected by systemic disease or other conditions that may contraindicate the use of auto-SED due to the presence of inflammatory mediators in the serum of the same. UCBS has a higher concentration of GF, such as EGF, TGF- $\beta$, NGF, and VEGF, compared to other blood derived preparations [46,82-84]. Nevertheless, UCBS contains a lower level of IGF-1 and vitamin A compared to peripheral blood serum but higher compared to tears [83]. It has been shown that blood samples collected from young mother $(<30$ years $)$ has a higher concentration of EGF, along with longer labour duration $(>6 \mathrm{~h})$, and higher CD34+ cell content $\left(0.05 \times 10^{6} / \mathrm{mL}\right)$. This pre-selection may be helpful to obtain UCBS with the ideal concentrations in EGF for healing corneal wounds without the need of GF laboratory dosages [85].

\section{Clinical Results}

UCBS eye drops were investigated as possible therapy of DED [46,82,86], PED [87-90], acute chemical burns [91,92], oGVHD [93], RCE [94], after PK [95], laser epithelial keratomileusis (LASEK) [96], Hansen's disease [97], and NK [98,99] (Table 3). A significant reduction of subjective discomfort symptoms associated with an improvement of tear stability, and recovery of the corneal sensitivity and keratopathy after UCBS treatment was shown in all studies in severe DED patients, with a high degree of satisfaction upon instillation. PED refractory to previous medical management [87-89] showed faster healing, no recurrence three months after the end of UCBS treatment, and higher increase of goblet cell density as compared to autologous serum treatment in SS patients [90]. UCBS also was shown to significantly ameliorate sub-basal corneal nerve morphology by an in vivo confocal microscopy study, suggesting a role of neurotrophic factors contained in UCBS [84] in its mechanism of action. These positive results were confirmed also in severe DED associated with oGVHD, in which symptom score, corneal sensitivity, TBUT, and keratoepitheliopathy score improved significantly after 2 months of UCBS treatment, and the improvements were maintained by 6 months after treatment [93]. The treatment with UCBS was compared to auto-SED [91] and amniotic membrane [92] treatments in patients with ocular chemical burns, showing a higher effectiveness in the ocular surface restoration and, in particular, in complete re-epithelialization already after $3 \pm 4$ weeks and reduced corneal haze. Yoon et al. evaluated the efficacy of UCBS in patients affected by RCE, reporting a mean healing time of 4 weeks and a reduced number of recurrences [94]. UCBS seems to be useful in the treatment of NK as it contains high levels of neurotrophic factors such as substance P, IGF-1, and NGF. In particular, a study on 28 eyes with NK reported complete epithelial defect healing in all eyes, with a mean healing time of $4.4 \pm 4.0$ weeks [98]. UCBS was also used in adjunct to conventional treatments after LASEK and was successful in reducing the early postoperative corneal haze and in improving tear film and ocular surface parameters [96]. Both auto-SED and UCBS treatments were effective in restoring the tear proteomic profile and conjunctival cytology in DED associated with leprosy [97], which includes corneal anaesthesia and severe epithelial squamous metaplasia. The UCBS treatment was proven in maintaining longer these beneficial effects after treatment. 
Table 3. Summary of the studies on the use of UCBS. Legend: Auto-SED = Autologous serum eye drops; AMT = Amniotic membrane transplantation; BSS: Balanced salt solution; $\mathrm{CIC}=$ Conjunctival impression cytology; $\mathrm{CMC}=$ Carboxymethylcellulose; $\mathrm{d}=$ day; DALK = Deep anterior lamellar keratoplasty; $\mathrm{DED}=\mathrm{Dry}$ eye disease; FS = Fluorescein staining; GVHD = Graft versus host disease; I = interventional; ISS = Isotonic Saline Solution; LASEK = laser epithelial keratomileusis; M = Month; OSDI = Ocular Surface Disease Index; P = Prospective; PED = Persistent epithelial defects; PK = Penetrating Keratoplasty; RCT = randomized controlled trial; RBS = Rose Bengal staining; SS = Sjogren's syndrome; ST = Schirmer test; TBUT = Tear Break Up Time; wks = weeks.

\begin{tabular}{|c|c|c|c|c|c|c|c|c|c|c|c|c|c|}
\hline $\begin{array}{l}\text { Study First } \\
\text { Name, Year }\end{array}$ & $\begin{array}{l}\text { Evidence } \\
\text { Level }\end{array}$ & Design & Condition & Inclusion Criteria & $\begin{array}{l}\text { Patients } \\
(n)\end{array}$ & $\begin{array}{c}\text { Controls } \\
(n)\end{array}$ & Control Arm & $\begin{array}{l}\text { Solvent } \\
\text { Composition }\end{array}$ & Dilution & Posology & $\begin{array}{l}\text { Duration of } \\
\text { Treatment }\end{array}$ & Main Outcomes & Results \\
\hline $\begin{array}{l}\text { Vajpayee } 2003 \\
{[88]}\end{array}$ & 1 & RCT & PED & $\begin{array}{l}\text { Refractory to treatments } \\
\text { (tear substitute, } \\
\text { patching, and contact } \\
\text { lens) }\end{array}$ & 31 & 29 & Auto-SED & ISS & $20 \%$ & $6 \times / \mathrm{d}$ & $3 \mathrm{wks}$ & $\begin{array}{l}\text { BCVA, FS, TBUT, ST, and } \\
\text { PED size }\end{array}$ & $\begin{array}{l}\text { Improvement of } \\
\text { re-epithelization rate in } \\
\text { UCBS group }\end{array}$ \\
\hline Yoon 2005 [89] & 3 & $\mathrm{P}, \mathrm{I}$ & PED & $\begin{array}{l}\text { PED refractory to } \\
\text { treatments; persisted for } \\
\text { at least } 2 \text { weeks }\end{array}$ & 14 & 1 & 1 & ISS & $20 \%$ & $6 \times / \mathrm{d}$ & 2 wks-1 M & PED area & $\begin{array}{l}43 \% \text { healing within } 2 \text { weeks; } \\
43 \% \text { healing within } 4 \text { weeks }\end{array}$ \\
\hline Yoon 2006 [82] & 2 & $\mathrm{P}, \mathrm{I}$ & DED & $\begin{array}{c}\text { Refractory to treatments. } \\
\text { DED symptoms }> \\
3 \text { months, TBUT }<5 \mathrm{~s}, \\
\text { ST }<5 \mathrm{~mm} / \mathrm{min}, \\
\text { positive FS or RBS }\end{array}$ & 31 & 1 & 1 & ISS & $20 \%$ & $6-10 \times / \mathrm{d}$ & $2 \mathrm{Ms}$ & $\begin{array}{l}\text { Subjective symptoms, } \\
\text { TBUT, , ST, corneal } \\
\text { sensitivity, and FS }\end{array}$ & $\begin{array}{l}\text { Improvement of symptoms, } \\
\text { TBUT, and FS }\end{array}$ \\
\hline Yoon 2007 [90] & 2 & $\mathrm{P}, \mathrm{I}$ & DED & $\begin{array}{l}\text { Refractory to treatments. } \\
\text { DED symptoms }> \\
3 \text { months, TBUT }<5 \mathrm{~s}, \\
\text { ST }<5 \mathrm{~mm} / \mathrm{min}, \\
\text { positive FS or RBS }\end{array}$ & 27 & 21 & Auto-SED & ISS & $20 \%$ & $6-10 \times / \mathrm{d}$ & $2 \mathrm{Ms}$ & $\begin{array}{l}\text { Symptom scoring, corneal } \\
\text { sensitivity, TBUT, ST, tear } \\
\text { clearance rate, FS, and CIC }\end{array}$ & $\begin{array}{c}\text { Symptoms, TBUT, FS, and } \\
\text { CIC findings improved in } \\
\text { both groups. Symptoms } \\
\text { and FS were lower in the } \\
\text { CBS group }\end{array}$ \\
\hline Yoon 2007 [93] & 2 & $\mathrm{P}, \mathrm{I}$ & $\begin{array}{l}\text { DED } \\
\text { (GVHD) }\end{array}$ & $\begin{array}{c}\text { Refractory to treatments, } \\
\text { TBUT }<5 \text {, ST }< \\
5 \mathrm{~mm} / \mathrm{min} \text {, positive FS }\end{array}$ & 12 & 1 & I & ISS & $20 \%$ & $6-10 \times / \mathrm{d}$ & $6 \mathrm{Ms}$ & $\begin{array}{c}\text { Subjective symptoms, } \\
\text { TBUT, ST, corneal } \\
\text { sensitivity test, FS, and tear } \\
\text { clearance rate }\end{array}$ & $\begin{array}{l}\text { Significant improvement in } \\
\text { symptoms, corneal } \\
\text { sensitivity, TBUT, and FS }\end{array}$ \\
\hline Yoon 2007 [98] & 2 & $\begin{array}{c}\mathrm{P}, \\
\text { non-comparative } \\
\text { case series }\end{array}$ & e NK & $\begin{array}{l}\text { Refractory to treatment } \\
\text { (tear substitute and } \\
\text { contact lens) }\end{array}$ & 28 & 1 & 1 & ISS & $20 \%$ & $6 \times / \mathrm{d}$ & $2-4 \mathrm{wks}$ & $\begin{array}{l}\text { Epithelial healing time, } \\
\text { BCVA, and corneal } \\
\text { sensitivity }\end{array}$ & $\begin{array}{l}100 \% \text { corneal healing after } \\
\quad 4 \text { weeks }\end{array}$ \\
\hline $\begin{array}{c}\text { Sharma } 2011 \\
\text { [91] }\end{array}$ & 1 & RCT & $\begin{array}{l}\text { Acute } \\
\text { Chemical } \\
\text { Burn }\end{array}$ & $\begin{array}{l}\text { Acute chemical burns of } \\
\text { grades III, IV, and V } \\
\text { (Dua's classification) }\end{array}$ & $\begin{array}{l}\text { Group 1: } \\
12\end{array}$ & $\begin{array}{l}\text { Group 2: } \\
\quad 11 \\
\text { Group 3: } \\
\quad 10\end{array}$ & $\begin{array}{l}\text { Group 2: } \\
\text { Auto-SED } \\
\text { Group 3: } \\
\text { Medical } \\
\text { Treatment }\end{array}$ & ISS & $20 \%$ & $10 \times / \mathrm{d}$ & $3 \mathrm{Ms}$ & $\begin{array}{l}\text { Time to epithelialization, } \\
\text { subjective symptoms, PED } \\
\text { area, extent of limbal } \\
\text { ischemia, corneal clarity, } \\
\text { and symblepharon } \\
\text { formation }\end{array}$ & $\begin{array}{l}\text { Significant reduction of } \\
\text { time to epithelialization } \\
\text { after CBS therapy } \\
\text { compared to AS and } \\
\text { medical treatment }\end{array}$ \\
\hline Yoon 2011 [94] & 2 & $\begin{array}{c}\text { P, I, } \\
\text { case-control }\end{array}$ & RCE & History of RCE & 18 & 17 & Tear substitute & ISS & $20 \%$ & $4-6 \times / d$ & 1 year & Number of recurrences & $\begin{array}{l}\text { Reduction of recurrences in } \\
\text { UCBS group }\end{array}$ \\
\hline
\end{tabular}


Table 3. Cont.

\begin{tabular}{|c|c|c|c|c|c|c|c|c|c|c|c|c|c|}
\hline $\begin{array}{l}\text { Study First } \\
\text { Name, Year }\end{array}$ & $\begin{array}{c}\text { Evidence } \\
\text { Level }\end{array}$ & Design & Condition & Inclusion Criteria & $\begin{array}{c}\text { Patients } \\
(n)\end{array}$ & $\begin{array}{c}\text { Controls } \\
(n)\end{array}$ & Control Arm & $\begin{array}{l}\text { Solvent } \\
\text { Composition }\end{array}$ & Dilution & Posology & $\begin{array}{c}\text { Duration of } \\
\text { Treatment }\end{array}$ & Main Outcomes & Results \\
\hline $\begin{array}{l}\text { Versura } 2013 \\
\quad[46]\end{array}$ & 2 & P, I & $\begin{array}{l}\text { PED } \\
\text { (GVHD } \\
\text { and SS) }\end{array}$ & $\begin{array}{c}\text { DED symptoms, } \\
\text { positive FS or RBS, ST }< \\
5 \mathrm{~mm} / 5 \mathrm{~min} \text { or TBUT }< \\
5 \mathrm{~s}\end{array}$ & 30 & l & 1 & $\begin{array}{l}\text { Phosphate } \\
\text { buffered } \\
\text { saline }\end{array}$ & $20 \%$ & $8 \times / \mathrm{d}$ & $1 \mathrm{M}$ & $\begin{array}{c}\text { PED area, subjective } \\
\text { symptom (OSDI), ST I, } \\
\text { TBUT, tear osmolarity, } \\
\text { corneal esthesiometry, and } \\
\text { CIC }\end{array}$ & $\begin{array}{l}\text { Significant reduction of } \\
\text { epithelial damage }\end{array}$ \\
\hline Yoon 2013 [96] & 2 & $\begin{array}{c}\text { P, I, } \\
\text { case-control }\end{array}$ & $\begin{array}{l}\text { Epithelial } \\
\text { defect } \\
\text { post-LASEK }\end{array}$ & $\begin{array}{l}\text { Patients underwent } \\
\text { LASEK }\end{array}$ & 32 & 28 & Tear substitute & ISS & $20 \%$ & $4-6 \times / d$ & $3 \mathrm{Ms}$ & $\begin{array}{l}\text { Epithelial healing time, } \\
\text { BCVA, Haze score (0-4), ST, } \\
\text { and TBUT }\end{array}$ & $\begin{array}{l}\text { Improvement of corneal } \\
\text { haze and tear film } \\
\text { parameters }\end{array}$ \\
\hline $\begin{array}{l}\text { Erdem } 2014 \\
\quad[87]\end{array}$ & 2 & P, I & PED & $\begin{array}{l}\text { Refractory to treatment } \\
\text { (tear substitute and } \\
\text { patching contact lens) }\end{array}$ & 14 & I & l & ISS & $20 \%$ & $\begin{array}{c}10 \times / d \\
\text { then } 5 x / d\end{array}$ & $3 \mathrm{wks}$ & PED area & $75 \%$ healing within $12 \mathrm{ds}$ \\
\hline $\begin{array}{l}\text { Mukhopadhyay } \\
2015 \text { [97] }\end{array}$ & 1 & RCT & $\begin{array}{c}\text { DED } \\
\text { (Hansen's } \\
\text { disease) }\end{array}$ & $\mathrm{ST}<5 \mathrm{~mm} / 5 \mathrm{~min}$ & 48 & $\begin{array}{l}\text { Group B: } \\
52 \\
\text { Group C: } \\
\quad 44 \\
\end{array}$ & $\begin{array}{c}\text { Group B: } \\
\text { Auto-SED 20\% } \\
\text { Group C: Tear } \\
\text { substitute } \\
\end{array}$ & ISS & $20 \%$ & $6-10 \times / d$ & $6 \mathrm{wks}$ & $\begin{array}{l}\text { Subjective symptom, ST I, } \\
\text { TBUT, and CIC }\end{array}$ & $\begin{array}{l}\text { Better improvement of } \\
\text { clinical parameters in CBS } \\
\text { group }\end{array}$ \\
\hline $\begin{array}{c}\text { Sharma } 2016 \\
\quad[92]\end{array}$ & 1 & RCT & $\begin{array}{l}\text { Acute } \\
\text { Chemical } \\
\text { Burn }\end{array}$ & $\begin{array}{l}\text { Acute chemical burns of } \\
\text { grades III, IV, and V } \\
\text { (Dua's classification) }\end{array}$ & $\begin{array}{l}\text { Group 3: } \\
\quad 15\end{array}$ & $\begin{array}{l}\text { Group 1: } \\
\quad 15 \\
\text { Group 2: } \\
\quad 15\end{array}$ & $\begin{array}{l}\text { Group 1: } \\
\text { Medical } \\
\text { treatment } \\
\text { Group 2: AMT, } \\
\text { Medical } \\
\text { treatment } \\
\end{array}$ & 1 & $20 \%$ & $10 \times / \mathrm{d}$ & Open & $\begin{array}{l}\text { Subjective symptoms, } \\
\text { TBUT, and ST }\end{array}$ & $\begin{array}{l}\text { UCS and AMT are equally } \\
\text { efficacious }\end{array}$ \\
\hline $\begin{array}{c}\text { Giannaccare } \\
2017[86]\end{array}$ & 2 & P, I & DED & $\begin{array}{c}\text { DED symptoms, } \\
\text { positive FS or RBS, } \mathrm{ST}< \\
5 \mathrm{~mm} / 5 \mathrm{~min} \text { or TBUT }< \\
5 \mathrm{~s}\end{array}$ & 20 & / & 1 & ISS & $20 \%$ & $8 \times / \mathrm{d}$ & $4 \mathrm{Ms}$ & $\begin{array}{l}\text { Subjective symptom (OSDI), } \\
\text { ST I, TBUT, FS, and corneal } \\
\text { sensitivity }\end{array}$ & $\begin{array}{l}\text { Significant improvement of } \\
\text { all clinical parameters }\end{array}$ \\
\hline $\begin{array}{c}\text { Kamble } 2017 \\
{[95]}\end{array}$ & 1 & RCT & $\begin{array}{l}\text { Epithelial } \\
\text { defect post- } \\
\text { keratoplasty }\end{array}$ & $\begin{array}{l}\text { Epithelial defect post } \\
\text { PK and DALK }\end{array}$ & $\underset{35}{\text { Group 1: }}$ & $\begin{array}{l}\text { Group 2: } \\
\quad 35 \\
\text { Group 3: } \\
\quad 35\end{array}$ & $\begin{array}{l}\text { Group 2: } \\
\text { Auto-SED 20\% } \\
\text { Group 3: Tear } \\
\text { substitute }\end{array}$ & BSS & $20 \%$ & $6 \times / \mathrm{d}$ & Until healing & Rate of re-epithelialization & $\begin{array}{c}\text { Rate of re-epithelialization } \\
\text { comparable between CBS } \\
\text { and Auto-SED groups }\end{array}$ \\
\hline
\end{tabular}




\section{Platelet Derived Eye Drops}

Platelets play a main role in the wound healing process, since they have high concentrations of GFs and cytokines contained in their $\alpha$-granules, such as PDGF, TGF- $\beta$, and platelet factor IV [100].

Platelets-based preparations are extremely versatile; exist under forms of variable solidity from liquid to gel; and have been largely used in regenerative medicine, orthopaedic and maxillo-facial surgery in order to promote tissue healing through the delivery of several bioactive factors [22]. Various preparations (namely PRP, PRGF, and platelet lysate) have quite recently been introduced as possible therapy of different ocular surface disorders.

In platelet-derived eye drops, the autologous source still represents the most used product in DED patients, whereas allogeneic PRP, developed for other fields of application, is still at its beginning as an eye-drop treatment.

\subsection{Preparations}

There is a large heterogeneity among PRP separation systems regarding concentrations of platelets, leukocytes, and growth factors in PRP. The choice for the most appropriate type of PRP should be based on the specific clinical field of application. For each preparation, we detail below the most used in the treatment of DED, as they appear in the literature.

Platelet-rich plasma is obtained from plasma that has a platelet concentration of over $1 \times 10^{6} / \mathrm{mL}$. Thirty $\mathrm{mL}$ of the patient's venous blood is drawn in tubes with $3.2 \%$ sodium citrate in order to prevent platelet activation prior to its use. A first centrifugation with low forces (10 min at soft spin from $200 \mathrm{~g}$ to $600 \mathrm{~g}$ ) separates the whole blood into three layers: an upper layer that contains mostly platelets and white blood cells (WBC) called platelet-poor plasma (PPP); an intermediate thin layer of whitish color called buffy coat (BC), rich in WBC; and a bottom layer that consists mostly of red blood cells (RBC). The upper layer and superficial buffy coat are transferred into another sterile tube for a second centrifugation step at higher speeds (10 min at hard spin from $700 \mathrm{~g}$ to $2300 \mathrm{~g}$ ) to concentrate platelets. The upper two-thirds of the volume (PPP) is discarded, while the lower one-third ( $5 \mathrm{~mL}$ of plasma) is homogenized by gently shaking the tube to create PRP. The product can be used either undiluted or diluted in BSS, sealed in vials or bottles, stored in the refrigerator at $4{ }^{\circ} \mathrm{C}$ for a maximum of 1 week or at $-20^{\circ} \mathrm{C}$ for longer periods. PRP acts by stimulating the release of PDGF, that is the first growth factor involved in the wound healing, and of TGF. Platelet-derived growth factor determines the increase of activated macrophages along with the development of new blood vessels. Transforming growth factor is able to induce chemotaxis and to control the epithelial proliferation, maintaining cells in an indifferent state. Furthermore, other important factors are the EGF that accelerates corneal epithelial proliferation and vascular endothelial growth factor (VEGF) and FGF-2 that take part in the angiogenesis process [101].

Plasma rich in growth factors. In the literature, a specific procedure is found, patented to standardize the PRGF preparation. Collected blood is centrifuged at $580 \mathrm{~g}$ for $8 \mathrm{~min}$ at room temperature in an Endoret System centrifuge (BTI Biotechnology Institute, S.L., Minano, Alava, Spain). The whole column of PRGF is collected after centrifugation using the Endoret ophthalmology kit (BTI Biotechnology Institute), avoiding the buffy coat that contains the leukocytes. The PRGF eye drops are incubated at $37^{\circ} \mathrm{C}$ for $1 \mathrm{~h}$; the obtained supernatant is then heat-treated at $56^{\circ} \mathrm{C}$ for $60 \mathrm{~min}$ to eliminate the complement fractions and other immunologic components and to obtain the so-called "immunosafe PRGF". Finally, plasma supernatants are filtered, aliquoted, and stored at $-20^{\circ} \mathrm{C}$. Before starting treatment, patients are taught to preserve the PRGF eye drops at $-20^{\circ} \mathrm{C}$ for maximum 3 months and to use each dispenser for 3 consecutive days [102].

Platelet lysate-Sixty $\mathrm{mL}$ of anticoagulated peripheral blood is collected from each patient and centrifuged to obtain an autologous platelet concentrate. The concentrate $\left(\right.$ at $\left.0.7 \times 10^{6} / \mathrm{mL}\right)$ is frozen and thawed (thermal shock $-80^{\circ} \mathrm{C} /+37^{\circ} \mathrm{C}$ ) to lyse platelets and GF release. The lysate is then diluted with sterile, balanced saline solution $(30 \% v / v)$ and aliquoted as 30 ready-to-use, sterile doses (ColSystem, Biomed Device Modena, Italy). A sample for microbiological investigations is taken the time of 
preparation. Next, the final preparation is frozen at $-20{ }^{\circ} \mathrm{C}$ and stored in the patients' own freezer for a maximum of 45 days $[103,104]$.

\subsection{Clinical Results}

Table 4 summarizes the characteristics and the main outcomes of clinical studies on the use of platelet-derived products for the treatment of ocular surface diseases. Fluorescein staining improved significantly in $72 \%$ of patients. The efficacy of PRP for the treatment of DED was investigated by Alio et al. who reported an improvement of symptoms in $89 \%$ of patients and a gain of at least 1 line of best-corrected visual acuity in $28 \%$ of cases. Furthermore, $56 \%$ of patients had improvements in the tear meniscus height from low to normal level; $86 \%$ of patients showed a significant improvement of conjunctival hyperaemia in slit-lamp appearance; and finally, fluorescein staining improved significantly in $72 \%$ of the cases [105]. The same research group treated with PRP 26 eyes suffering from post-LASIK DED, with improvements in symptoms in $85 \%$ of patients and a gain of $1-2$ lines of best-corrected visual acuity in $54 \%$ of them [106]. Alio et al. also employed topical PRP eye drops in 26 eyes with chronic non-healing corneal ulcers and reported healing of the ulcer in half of the eyes and improvement in inflammation and subjective symptoms in all of them [107].

Lopez-Plandolit used autologous plasma rich in PDGFs in 20 eyes affected by PED unresponsive to conventional treatment, reporting healing of the epithelial defects in $85 \%$ of cases after a mean therapeutic time of 10.9 weeks [108]. In another study, patients with ocular oGVHD unresponsive to conventional therapy were treated with autologous plasma rich in PDGF eye drops. Photophobia and TBUT improved in $82.6 \%$ and $86.9 \%$ of patients, respectively [109]. In 2017, the same authors evaluated the long-term efficacy of plasma rich in PDGF eye drops in 31 patients with oGVHD. After 36 months, symptoms and TBUT significantly improved and no adverse events occurred [103]. Kim et al. compared the healing efficacy of allo-SED and PRP in 28 eyes affected by PED and reported a higher healing rate in the group treated with PRP [110]. A randomized controlled trial on 20 eyes affected by grade III to V chemical injuries compared PRP eye drops with standard medical treatment or standard medical treatment alone. After 3 months of treatment, significantly higher improvements in corneal transparency and in visual acuity were found in patients who received PRP [111].

In an in vivo confocal microscopy study, Fea et al. reported a significant increase in basal epithelium cells density and sub-basal nerve plexus density and a decrease in Langerhans cell density in patients with SS-related DED treated with platelet lysate [112]. Lee et al. compared the efficacy of PRP eye drops and tear substitutes in patients with RCE and found a significantly lower frequency of recurrence in eyes receiving PRP eye drops [113].

Merayo-Lloves et al. evaluated the safety and efficacy of autologous plasma rich in PDGF eye drops in 83 patients with evaporative DED and reported a significant improvement in symptoms, best-corrected visual acuity, and Schirmer test [114]. The same research group investigated the use of PDGFs in patients with SS-related DED [102], NK [115], post-LASIK DED [116], and oGVHD [117]. Patients with SS-related DED showed a significant improvement in symptoms and best-corrected visual acuity after treatment [102]. Patients with DED following LASIK surgery showed an improvement in symptoms and Schirmer test after treatment [116]. Patients with oGVHD showed an improvement of symptoms, corneal staining, best-corrected visual acuity, TBUT, and Schirmer test [117].

A complete resolution of corneal ulcer was reported in $97.4 \%$ of patients with NK after a mean time of 11.4 weeks [115]. Similar results were obtained in $25 \mathrm{NK}$ patients treated by Wróbel-Dudzinska et al. with PRP eye drops, with complete healing of the corneal ulcer observed in $80 \%$ of patients, while improved symptoms and visual acuity observed in all of them [118]. In a randomized clinical trial, Garcia-Conca et al. compared PRP eye drops with tear substitutes in patients with hyposecretory DED [119]. Patients treated with PRP showed a significantly higher improvement in symptoms, visual acuity, conjunctival hyperaemia, corneal and conjunctival staining, Schirmer test, and tear osmolarity [119]. 
Table 4. Summary of the studies on the use of preparations from PRP (Platelet-Rich Plasma); PL = Platelet Lysate; PRGF = Platelet Rich in Growth Factors. Legend: Allo-SED = Allogenic serum eye drop; AMT = Amniotic membrane transplantation; $\mathrm{CIC}=$ Conjunctival impression cytology; $\mathrm{d}=\mathrm{day} ; \mathrm{DED}=\mathrm{Dry}$ eye disease; GVHD = Graft versus host disease; I = interventional; ISS = Isotonic Saline Solution; LASIK = Laser assisted in situ keratomileusis; M = Month; NaHy = Sodium hyalutonate; $\mathrm{NK}=$ Neurotrophic keratitis; OSDI = Ocular Surface Disease Index; P = Prospective; PED = Persistent epithelial defects; PRGF = plasma rich in growth factors; PRP = Platelet rich plasma; PL = Platelet lysate; RCT = Randomized controlled trial; RBS = Rose Bengal staining; SS = Sjogren's syndrome; ST = Schirmer test; TBUT $=$ Tear Break Up Time; wks = weeks.

\begin{tabular}{|c|c|c|c|c|c|c|c|c|c|c|c|c|c|c|}
\hline $\begin{array}{c}\text { Study, First } \\
\text { Name, Year, [ref] }\end{array}$ & $\begin{array}{l}\text { Evidence } \\
\text { Level }\end{array}$ & Product & Design & Disease & Inclusion Criteria & $\begin{array}{c}\text { Patients } \\
(n)\end{array}$ & $\begin{array}{c}\text { Controls } \\
(n)\end{array}$ & $\begin{array}{c}\text { Control } \\
\text { Arm }\end{array}$ & Solvent & Dilution & Posology & $\begin{array}{c}\text { Duration of } \\
\text { Treatment }\end{array}$ & Main Outcomes & Results \\
\hline Kim 2012 [109] & 2 & PRP & Retrospective & PED & $\begin{array}{l}\text { Refractory to } \\
\text { treatment (Tear } \\
\text { substitute) }\end{array}$ & 28 & 17 & Allo-SED & ISS & $20 \%$ & $4 \times / \mathrm{d}$ & Until healing & $\begin{array}{l}\text { Epithelial healing } \\
\text { time and rate }\end{array}$ & $\begin{array}{l}\text { Higher healing rate in } \\
\text { PRP group }\end{array}$ \\
\hline Alio 2007 [104] & 2 & PRP & $\mathrm{P}, \mathrm{I}$ & DED & $\begin{array}{c}\mathrm{FS}>50 \% \text {, clinical } \\
\text { signs of inflammation }\end{array}$ & 18 & 1 & 1 & ISS & 1 & $4-6 \times / d$ & $1 \mathrm{M}$ & $\begin{array}{c}\text { Subjective } \\
\text { symptoms, BCVA, } \\
\text { tear meniscus } \\
\text { height, TBUT, FS, } \\
\text { and CIC }\end{array}$ & $\begin{array}{c}\text { Improvement of } \\
\text { symptoms }(89 \%), \text { BCVA } \\
(28 \%) \text {, tear meniscus } \\
\text { height }(56 \%), \text { TBUT } \\
(50 \%) \text {, and FS }(72 \%)\end{array}$ \\
\hline Alio 2007 [106] & 2 & $\begin{array}{l}\text { PRP vs. } \\
\text { AMT }\end{array}$ & $\mathrm{P}, \mathrm{I}$ & $\begin{array}{l}\text { Corneal } \\
\text { ulcers }\end{array}$ & $\begin{array}{l}\text { Refractory to } \\
\text { treatment }\end{array}$ & 38 & 1 & 1 & ISS & 1 & $6 \times / \mathrm{d}$ & $6 \mathrm{Ms}$ & $\begin{array}{l}\text { Ulcer size, } \\
\text { inflammation, } \\
\text { healing, BCVA, } \\
\text { and subjective } \\
\text { symptoms } \\
\end{array}$ & $\begin{array}{l}\text { Improvement of signs } \\
\text { and symptoms }\end{array}$ \\
\hline Alio 2007 [105] & 3 & PRP & $\mathrm{P}, \mathrm{I}$ & $\begin{array}{c}\text { DED } \\
\text { post-LASIK }\end{array}$ & $\begin{array}{l}\text { Patients who } \\
\text { received LASIK }\end{array}$ & 13 & 1 & 1 & ISS & 1 & $6 \times / \mathrm{d}$ & $1 \mathrm{M}$ & $\begin{array}{c}\text { Subjective } \\
\text { symptoms, BCVA, } \\
\text { FS, and TBUT }\end{array}$ & $\begin{array}{c}\text { Improvement of } \\
\text { symptoms (85\%); BCVA } \\
\text { from } 1 \text { to } 2 \text { lines (54\%); } \\
\text { disappearance of FS } \\
(69 \%) \text {; increase of TBUT } \\
>2 \mathrm{~s}(46 \%)\end{array}$ \\
\hline Lee 2016 [112] & 2 & PRP & Retrospective & RCE & $\begin{array}{l}\text { Patients treated with } \\
\text { conventional therapy }\end{array}$ & 47 & 20 & $\begin{array}{l}\text { Tear } \\
\text { substitute }\end{array}$ & ISS & $20 \%$ & $\begin{array}{c}\text { Every } 2 \mathrm{~h} \text { for } \\
2 \mathrm{Ms}, 4 \times / \mathrm{d} \text { for } \\
4 \mathrm{Ms}\end{array}$ & $6 \mathrm{M}$ & Recurrence rate & $\begin{array}{l}\text { Reduced recurrence rate } \\
\text { in PRP group }\end{array}$ \\
\hline Panda 2012 [110] & 1 & PRP & RCT & $\begin{array}{l}\text { Chemical } \\
\text { injury }\end{array}$ & 1 & 20 & 10 & $\begin{array}{c}\text { Tear } \\
\text { substitute }\end{array}$ & ISS & 1 & $10 \times / \mathrm{d}$ & $3 \mathrm{Ms}$ & $\begin{array}{c}\text { Corneal } \\
\text { transparency and } \\
\text { BCVA }\end{array}$ & $\begin{array}{l}\text { Significant improvement } \\
\text { of corneal transparency } \\
\text { and BCVA in PRP group }\end{array}$ \\
\hline $\begin{array}{l}\text { García-Conca } \\
2018 \text { [118] }\end{array}$ & 1 & PRP & RCT & $\begin{array}{l}\text { Hyposecretory } \\
\text { DED }\end{array}$ & $\begin{array}{c}\mathrm{ST}<5.5 \mathrm{~mm}, \text { OSDI } \geq \\
13, \text { Oxford scale score } \\
\geq 1\end{array}$ & 83 & 39 & $\begin{array}{l}\text { NaHy, } \\
\text { Tear } \\
\text { substitute }\end{array}$ & ISS & 1 & $6 \times / \mathrm{d}$ & $30 \mathrm{ds}$ & $\begin{array}{c}\text { ST, tear } \\
\text { osmolarity, FS, } \\
\text { TBUT, } \\
\text { conjunctival } \\
\text { hyperaemia, } \\
\text { OSDI, and CIC }\end{array}$ & $\begin{array}{l}\text { Improvement of signs in } \\
\text { PRP group }\end{array}$ \\
\hline
\end{tabular}


Table 4. Cont

\begin{tabular}{|c|c|c|c|c|c|c|c|c|c|c|c|c|c|c|}
\hline $\begin{array}{c}\text { Study, First } \\
\text { Name, Year, [ref] }\end{array}$ & $\begin{array}{l}\text { Evidence } \\
\text { Level }\end{array}$ & Product & Design & Disease & Inclusion Criteria & $\begin{array}{c}\text { Patients } \\
(n)\end{array}$ & $\begin{array}{c}\text { Controls } \\
(n)\end{array}$ & $\begin{array}{c}\text { Control } \\
\text { Arm }\end{array}$ & Solvent & Dilution & Posology & $\begin{array}{c}\text { Duration of } \\
\text { Treatment }\end{array}$ & Main Outcomes & Results \\
\hline Avila 2018 [120] & 1 & $\begin{array}{c}\text { PRP } \\
\text { injected }\end{array}$ & RCT & DED (SS) & $\begin{array}{l}\text { Patients who did not } \\
\text { receive medications } \\
\text { like ciclosporin or } \\
\text { topical steroids or } \\
\text { lacrimal plugs and } \\
\text { lacrimal occlusion }\end{array}$ & 30 & 15 & $\begin{array}{c}\text { Tear } \\
\text { substitute }\end{array}$ & ISS & 1 & $1 \mathrm{~mL}$ PRP & & FS and TBUT & $\begin{array}{l}\text { Improvement of lacrimal } \\
\text { production and TBUT; } \\
\text { reduction FS in PRP } \\
\text { group }\end{array}$ \\
\hline $\begin{array}{c}\text { Wróbel-Dudzińska } \\
2018 \text { [117] }\end{array}$ & 2 & PRP & P, I & NK & $\begin{array}{l}\text { Refractory to } \\
\text { treatment }\end{array}$ & 25 & I & 1 & I & I & $5 \times / \mathrm{d}$ & $3 \mathrm{Ms}$ & $\begin{array}{l}\text { BCVA, healing of } \\
\text { corneal surface, } \\
\text { subjective } \\
\text { symptoms, and } \\
\text { corneal thickness }\end{array}$ & $\begin{array}{l}\text { Improvement of BCVA; } \\
\text { PED full healing }(80 \%) ; \\
\text { lack of discomfort and } \\
\text { photophobia }(96 \%) ; \text { no } \\
\text { progression of corneal } \\
\text { damage }\end{array}$ \\
\hline $\begin{array}{c}\text { Pezzotta } 2017 \\
{[102]}\end{array}$ & 2 & PL & $\mathrm{P}$ & DED (GVHD) & $\begin{array}{c}\text { Refractory to } \\
\text { treatment (tear } \\
\text { substitute for at least } \\
\text { 3 Ms) }\end{array}$ & 23 & I & I & I & 1 & $4 \times / \mathrm{d}$ & $6 \mathrm{Ms}$ & $\begin{array}{c}\text { Symptoms, TBUT, } \\
\text { and FS }\end{array}$ & $\begin{array}{c}\text { Improvement of } \\
\text { symptoms (74\%), TBUT } \\
(86.9 \%) \text {, and FS }(69.6 \%)\end{array}$ \\
\hline Fea 2016 [111] & 2 & PL & $\mathrm{P}$, case-control & DED (SS) & $\begin{array}{c}\text { Severe DED, OSDI } \geq \\
23 \text {, Oxford scale score } \\
\geq 1 \text {; refractory to } \\
\text { treatment for more } \\
\text { than } 2 \mathrm{Ms} \text { (tear } \\
\text { substitute, steroids, } \\
\text { cyclosporine A, or } \\
\text { allo-SED) }\end{array}$ & 30 & 10 & $\begin{array}{c}\text { Tear } \\
\text { substitute }\end{array}$ & ISS & $50 \%$ & $4 \times / \mathrm{d}$ & $3 \mathrm{Ms}$ & $\begin{array}{c}\text { OSDI, ST, FS, } \\
\text { BCVA, and TBUT }\end{array}$ & $\begin{array}{l}\text { Improvement of OSDI, } \\
\text { FS, and TBUT in PL } \\
\text { group }\end{array}$ \\
\hline Zallio 2016 [103] & 2 & PL & $\mathrm{P}, \mathrm{I}$ & DED (GVHD) & $\begin{array}{l}\text { Recent diagnosis of } \\
\text { GVHD }\end{array}$ & 26 & 1 & 1 & BSS & $30 \%$ & $6 \times / d$ & 1 year & 1 & $\begin{array}{l}\text { Improvement in } \\
\text { symptoms ( } 91 \%) ; \\
\text { remission of corneal } \\
\text { damage, }(86 \%) \text { and } \\
\text { improved National } \\
\text { Institutes of Health } \\
\text { scores }(73 \%)\end{array}$ \\
\hline $\begin{array}{l}\text { Lopez-Plandolit } \\
2010[107]\end{array}$ & 2 & PRGF & P, I & PED & $\begin{array}{l}\text { Refractory to medical } \\
\text { and surgical } \\
\text { treatments }\end{array}$ & 18 & 1 & I & ISS & 1 & $\begin{array}{l}\text { Every } 2 \mathrm{~h} \text { for } \\
3 \mathrm{~d} \text {, then } \\
\text { variable }\end{array}$ & Until healing & $\begin{array}{l}\text { Epithelial healing } \\
\text { rate and time }\end{array}$ & $\begin{array}{l}85 \% \text { healing within a } \\
\text { mean of } 11 \text { weeks }\end{array}$ \\
\hline $\begin{array}{l}\text { Sanchez-Avila } \\
2017 \text { [101] }\end{array}$ & 2 & PRGF & Retrospective & DED (SS) & SS & 26 & 1 & I & ISS & 1 & $4 \times / \mathrm{d}$ & $\begin{array}{c}6 \text { wks } \\
(=1 \text { cycle })\end{array}$ & $\begin{array}{l}\text { OSDI, VAS, and } \\
\text { BCVA }\end{array}$ & $\begin{array}{l}\text { Improvement of OSDI } \\
\text { score, BCVA, VAS } \\
\text { frequency, and VAS } \\
\text { severity }\end{array}$ \\
\hline
\end{tabular}


Table 4. Cont

\begin{tabular}{|c|c|c|c|c|c|c|c|c|c|c|c|c|c|c|}
\hline $\begin{array}{c}\text { Study, First } \\
\text { Name, Year, [ref] }\end{array}$ & $\begin{array}{l}\text { Evidence } \\
\text { Level }\end{array}$ & Product & Design & Disease & Inclusion Criteria & $\begin{array}{c}\text { Patients } \\
(n)\end{array}$ & $\begin{array}{c}\text { Controls } \\
(n)\end{array}$ & $\begin{array}{c}\text { Control } \\
\text { Arm }\end{array}$ & Solvent & Dilution & Posology & $\begin{array}{c}\text { Duration of } \\
\text { Treatment }\end{array}$ & Main Outcomes & Results \\
\hline $\begin{array}{l}\text { Sanchez-Avila } \\
2018 \text { [114] }\end{array}$ & 2 & PRGF & Retrospective & $\begin{array}{c}\text { NK stage } 2 \\
\text { and } 3\end{array}$ & $\begin{array}{c}\text { ST }<5 \mathrm{~mm}, \text { TBUT }< \\
5 \mathrm{~s} \text {, severity of } \\
\text { subjective symptoms } \\
\text { in the level of } \\
\text { severity of dry eye }\end{array}$ & 31 & I & I & ISS & I & $4 \times / \mathrm{d}$ & $\begin{array}{c}6 \text { wks }(1 \\
\text { cycle) }\end{array}$ & $\begin{array}{l}\text { Ulcer closure at } 4 \\
\text { weeks, OSDI, } \\
\text { VAS, and BCVA }\end{array}$ & $\begin{array}{c}\text { Resolution of corneal } \\
\text { defect/ulcer }(97.4 \%) \text { in } \\
\text { 11.4 weeks; reduction of } \\
\text { OSDI (60.9\%), VAS } \\
\text { frequency }(59.9 \%) \text {, and } \\
\text { VAS severity (57\%); } \\
\text { improvement of BCVA } \\
(52.8 \%)\end{array}$ \\
\hline $\begin{array}{l}\text { Sanchez-Avila } \\
2018 \text { [115] }\end{array}$ & 2 & PRGF & $\begin{array}{c}\text { retrospective, } \\
\text { comparative, } \\
\text { and } \\
\text { descriptive }\end{array}$ & $\begin{array}{c}\text { DED } \\
\text { post-LASIK }\end{array}$ & $\begin{array}{l}\text { Patients who } \\
\text { received LASIK }\end{array}$ & 79 & 39 & $\begin{array}{c}\text { Tear } \\
\text { substitute }\end{array}$ & ISS & I & $4 \times / \mathrm{d}$ & $\begin{array}{c}6 \text { wks }(1 \\
\text { cycle) }\end{array}$ & $\begin{array}{l}\text { VAS, OSDI, } \\
\text { BCVA, TBUT, ST, } \\
\text { and IOP }\end{array}$ & $\begin{array}{l}\text { Improvement in OSDI } \\
(38.12 \%), \text { VAS (41.89\%), } \\
\text { severity }(42.47 \%) \text {, and ST } \\
\text { (88.98\%) in PRGF group }\end{array}$ \\
\hline $\begin{array}{l}\text { Sanche-Avila } \\
2018 \text { [116] }\end{array}$ & 2 & PRGF & Retrospective & DED (GVHD) & $\begin{array}{c}\text { Refractory to } \\
\text { treatments for 3 Ms } \\
\text { (tear substitute, } \\
\text { topical/oral } \\
\text { antibiotics, corticoids } \\
\text { and antivirals, } \\
\text { contact lens, punctal } \\
\text { occlusion, Allo-SED, } \\
\text { cyclosporine, and } \\
\text { AMT) }\end{array}$ & 12 & I & I & ISS & I & $4 \times / \mathrm{d}$ & $\begin{array}{c}6 \text { wks }(1 \\
\text { cycle) }\end{array}$ & $\begin{array}{l}\text { Resolution of } \\
\text { corneal ulcers }\end{array}$ & $\begin{array}{l}\text { Improvement in the area } \\
\text { (75.7\%) and density } \\
(73.3 \%) \text { corneal staining, } \\
\text { BCVA (74.7\%), OSDI } \\
(75.4 \%) \text {, visual analog } \\
\text { score frequency }(81.4 \%) \text {, } \\
\text { and VAS severity }(81.9 \%) \\
\text { and an increase of } 3.8 \mathrm{sin} \\
\text { TBUT and } 6 \mathrm{~mm} \text { in ST }\end{array}$ \\
\hline $\begin{array}{l}\text { Merayo-Lloves } \\
2016[113]\end{array}$ & 2 & PRGF & Retrospective & $\begin{array}{l}\text { Evaporative } \\
\text { DED }\end{array}$ & $\begin{array}{l}\text { Refractory to } \\
\text { treatment (tear } \\
\text { substitute, topical } \\
\text { or/and systemic } \\
\text { corticosteroids, AS, } \\
\text { or cyclosporine) }\end{array}$ & 83 & 1 & 1 & ISS & 1 & $4 \times / \mathrm{d}$ & $6 \mathrm{wks}$ & $\begin{array}{l}\text { OSDI, BCVA, } \\
\text { VAS, and ST }\end{array}$ & $\begin{array}{c}\text { Reductions in the OSDI } \\
\text { (38.2\%), BCVA (27.4\%), } \\
\text { and VAS for frequency } \\
(32 \%) \text { and severity }(34 \%) \\
\text { and improvement in ST } \\
(177.5 \%)\end{array}$ \\
\hline
\end{tabular}


Due to its versatile methods of preparation, PRP can be used also as a solid preparation during reconstructive surgery of the ocular surface. A solid clot of PRP was used in combination with other surgical techniques, such as amniotic membrane transplantation and bovine pericardium membrane (Tutopach), to treat corneal ulcers and corneal perforations [120]. In a randomized controlled clinical trial, Avila et al. evaluated the administration of PRP as an injectable solution into the lacrimal gland in patients with SS-related DED. Compared to the control group, the intervention group showed a higher improvement in corneal staining, Schirmer test, TBUT, and symptoms [121].

\section{Data Analysis and Criticism}

Regulations vary from country to country for the use of blood-derived eye drops, which are classified differently according to local legislations-ranging from an unlicensed medicinal product ("special") to "simple" blood component-with variable degrees of restrictions.

Clinical recommendations on SED for severe ocular surface disease have been published by the Royal College of Ophthalmologists [122,123], with the proposal to regulate SED by enrolling patients in a national program of outcome reporting that includes frequency and duration of treatment, serious adverse events or reactions, and patient self-reported outcomes. In this report, a 50\% dilution in $0.9 \%$ sodium chloride is recommended (as provided by National Health Service Blood and Transplant, the only accredited SED production facility in the UK), only based on good practice points upon consensual expert opinion.

Data from our work were extracted from 55 papers of level of evidence $1(n=17)$ and $2(n=32)$, and only 6 papers were graded as level 3. All blood preparations used so far have been included for all sources and preparations of blood based treatments for ocular surface disease: auto-SED $(n=20$, Table 1); adult allo-SED ( $n=3$, Table 2); allogeneic UCBS eye drops $(n=15$, Table 3$)$; allogeneic platelet products $(n=17$, Table 4$)$ subdivided into PRP $(n=9)$; platelet lysate $(n=3)$; and PRGF $(n=5)$.

All studies showed a good profile in terms of safety and efficacy for all the products.

The list of ocular surface diseases treated with blood-based eye drops spans several conditions of different aetiology and is summarized in Figure 1. We were not able to find any information about the rationale for the product selection based on a specific condition or graded according to severity.

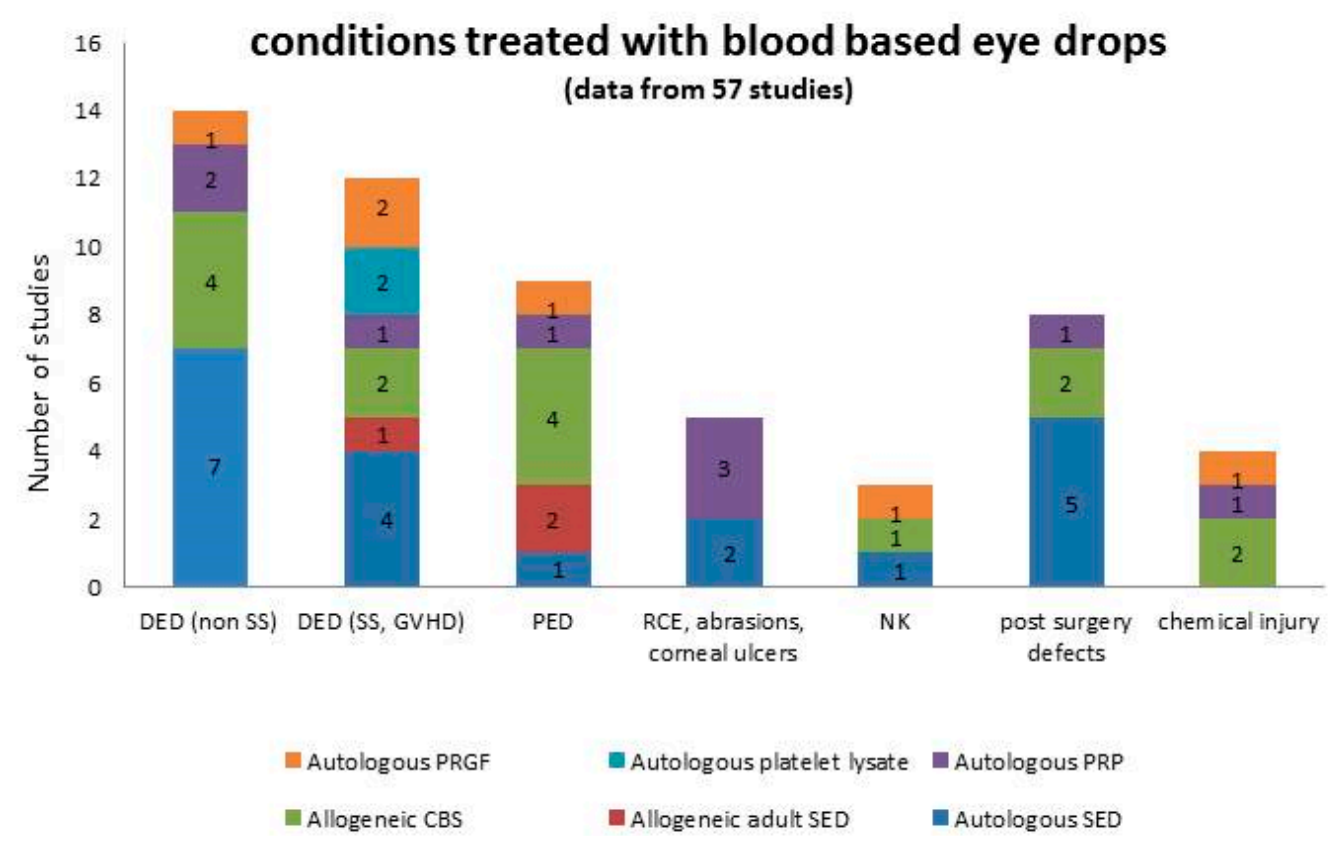

Figure 1. Summary of the conditions treated with blood-based eye drops, graphed in columns where each colour represents a specific product. Numbers in the columns represent the number of studies. 
Data highlights the elevated heterogeneity of processing of blood-based eye drops despite the assumption that any procedure in the preparation may impact the content of the active substances or may influence their delivery. Sterile saline was the most used diluent, and it was reported in 43 out of 55 studies. The alternative use of sodium hyaluronate or carboxymethyl cellulose or unspecified tear substitutes were reported in 8 out of 55 studies with the aim to improve the retention time of the product or to increase its availability, but results were too few and inconsistent to provide comparable data.

Dilution $20 \%$ was the most used percentage, reported in 31 out of 55 studies, followed by $50 \%$ (7 studies) and undiluted ( 3 studies). The rationale for choosing a dilution was not discussed in the totality of the studies; in the PRP section, the dilution was not even reported in 14 out of 18 studies included in the analysis.

Taken altogether, data suggest that the parameters of processing and use were considered more as an established habit of the centers over the years rather than a parameter to be tailored.

The conditions treated with blood-based eye drops are summarized in Table 1. Moderate and severe DED, eventually associated to autoimmune diseases and oGVHD, and PED were the most represented diseases treated with all the products. No indication on the choice of a specific product for a specific disease was recorded in the analysis.

Inclusion criteria considered for a given patient to enter a therapeutic program with blood-based eye drops are summarized in Figure 2. To be refractory to previous treatment (ranging from tear substitutes to therapeutic soft contact lenses, topical steroids, and $0.05 \%$ cyclosporine) was the most represented indication for the prescription, followed by severely impaired parameters of tear functions and subjective symptoms of discomfort indicating severe dryness. Despite an increasing interest in other disciplines concerning the application of blood-based products to pursue reduction of pain [124], no indication of the prescription of blood-based eye drops focused on ocular pain relief was found.

\section{inclusion criteria for blood based eye drops (data from 57 studies)}

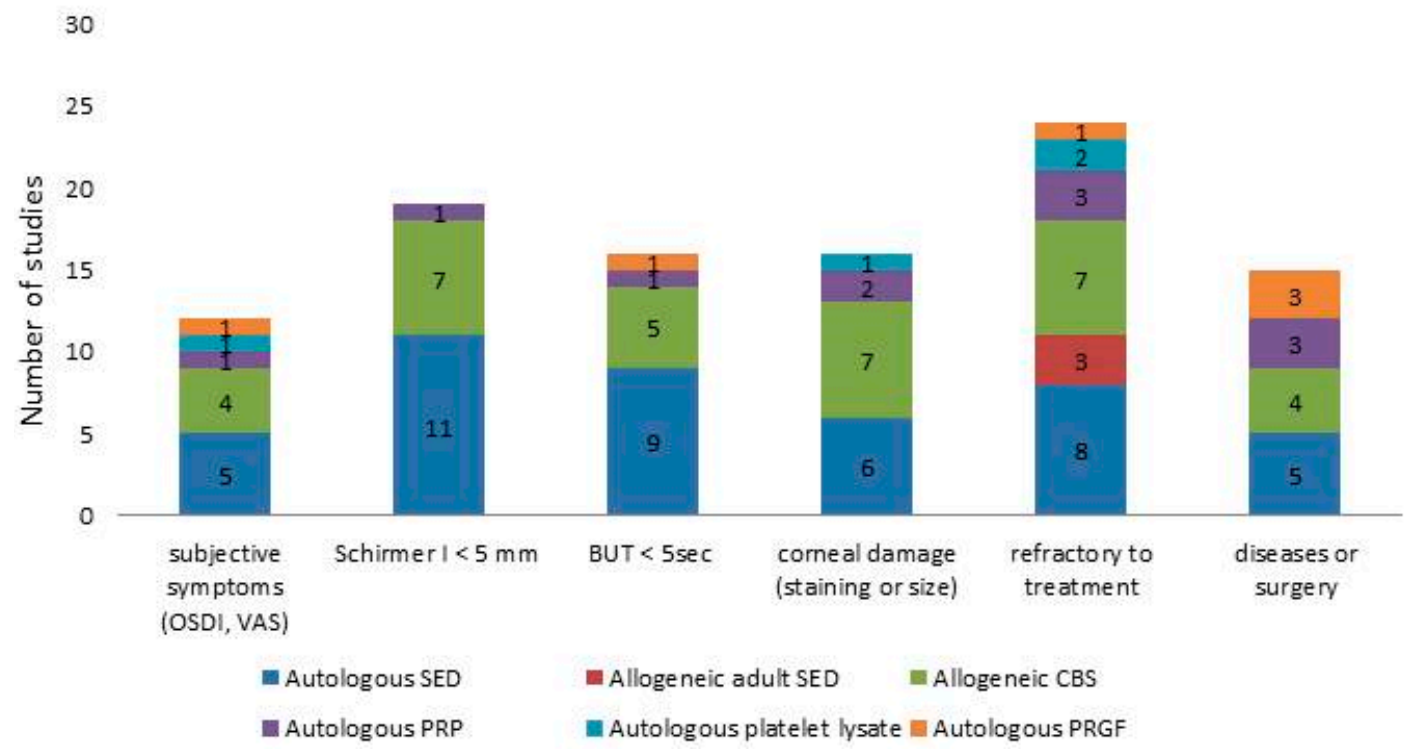

Figure 2. Summary of the inclusion criteria considered in patients entering a therapeutic program with blood-based eye drops, graphed in columns where each colour represents a specific product. Numbers in the columns represent the number of studies.

Posology of treatment was also extremely variable, and when specified, it ranged from one drop every hour to $3,4,6,8,10$, or 12 drops/day or to scaled regimens consisting of a higher frequency the first weeks of treatment and then decreasing. Beyond the obvious consideration that the amount of active compounds supplied relates to the posology, it is also an issue that tear substitutes may be 
necessary in adjunct to protect the surface in case of a regimen with few drops. No indication on eventual concurrent or rescue treatment allowed in cases of adverse events was found. No indication on dose size was found.

One month was the most reported time of treatment ( 8 studies), followed by 6 weeks ( 6 studies), 2 months ( 2 studies), 3 and 6 months ( 5 studies each), continuously for one year and until healing (2 studies each), or unspecified (in the remaining studies). No consideration on the eventual early stop of the treatment or on the retreatment parameters in terms of rationale to retreat and time interval of treatment suspension was found. The recurrence rate was considered in only two studies [62,94].

Parameters considered as main outcomes are summarized in Figure 3. Reduction of subjective symptoms and reduction of corneal damage (expressed either as reduction of staining and/or area size) were reported in almost all the studies. Despite the supply of epitheliotrophic growth factors, the healing time was seldom considered as an outcome in the studies.

\section{main outcomes with blood based eye drops \\ (data from 57 studies)}

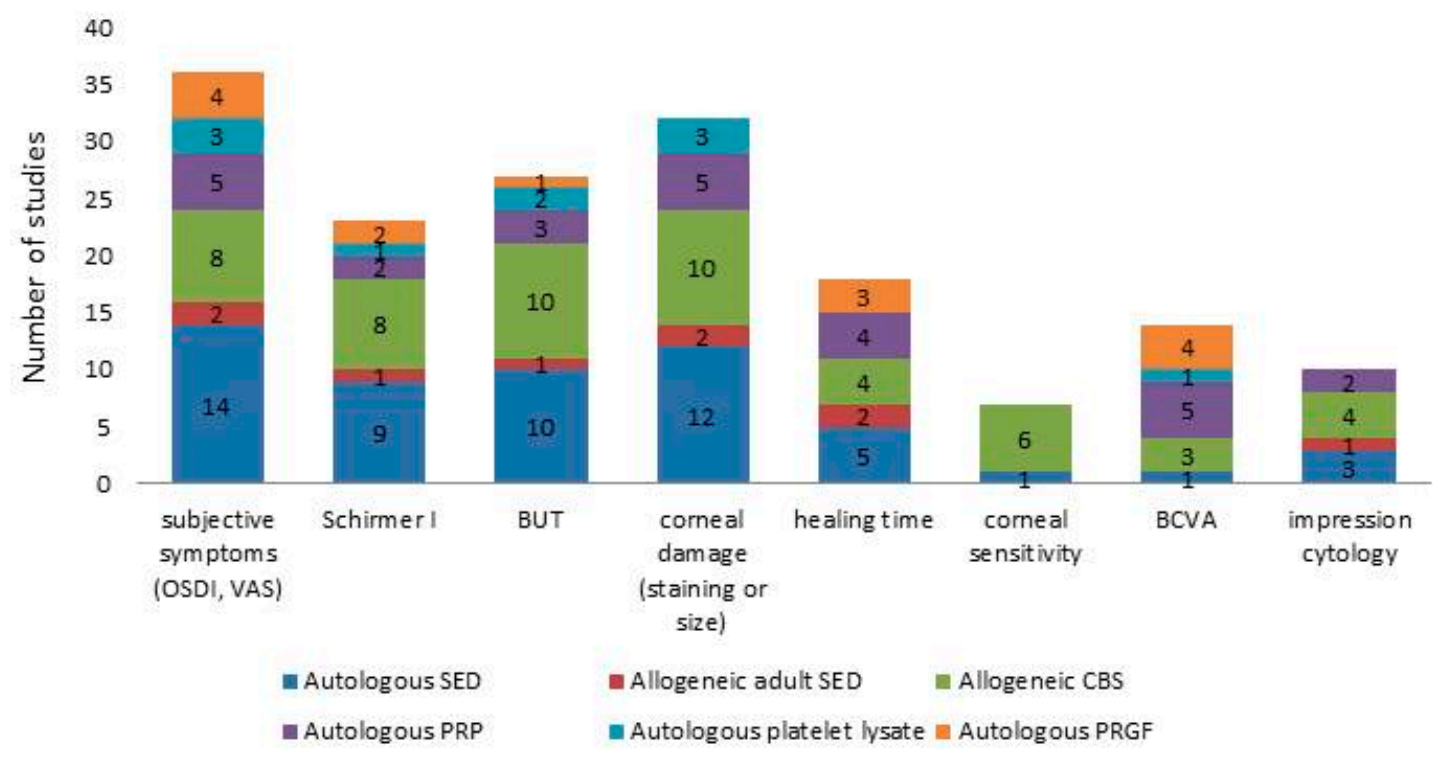

Figure 3. Summary of the main outcomes reported in patients treated with blood-based eye drops, graphed in columns where each colour represents a specific product. Numbers in the columns represent the number of studies.

The metrics used to score all the parameters were inconsistent throughout the studies, making it not possible to make a meta-analytic comparison.

\section{Conclusions}

Blood-based eye drops represent an emerging treatment option of different ocular surface disorders, as they supply a combination of active substances GFs and cytokines that mimic the function of natural tears.

Allogeneic sources seem to represent a rising innovation, allowing to obtain a customized eye drop on the base of the specific subtype of patients and ocular surface diseases.

However, further randomized clinical trials and internationally recognized harmonized guidelines are still needed to provide better evidence, to improve quality of the final products, and to lead to a more widespread use of these therapies in daily ophthalmological practice. Most importantly, future studies need to include short-, medium-, and long-term follow-up to determine if any benefit is maintained after treatment and for how long. 
There remains many unanswered questions regarding what might be considered optimal treatment, sketched as "The $5 \mathrm{Ws}$ (and $2 \mathrm{Hs}$ ) for blood-based eye drops", as follows.

Who is the patient to be treated, in terms of disease type, severity, and stage?

Why is a blood-based treatment needed, in terms of a target indication?

When is it appropriate to prescribe blood-based therapy, as too late is not always a good option?

Where are the products dispensed? Is a national/regional program a feasible solution to optimize resources?

What is the product of choice? Which source and preparation are targeted for a given patient? Is a patient self-report enough, or should the clinician who prescribed the product report the course, as surgeons do in organ transplants?

How is the product standardized in terms of processing to ensure optimal dilution, solvent, dispenser, and storage time?

How is treatment delivered to the ocular surface, in terms of posology, dose-size modulation, length of treatment, and number of cycles?

Preclinical studies are needed to standardize and compare blood based products, and an interdisciplinary work with transfusional medicine specialists is imperative to share information and competences.

Author Contributions: Conceptualization, P.V., F.B. and M.B.; methodology, F.B., M.R. and P.V.; software, M.R. and M.P.; validation, F.B., P.V. and M.B.; resources, F.B., M.R., M.P., and G.G.; data curation, F.B., M.R. and G.G.; writing—original draft preparation, F.B., M.R., M.B., M.P., G.G. and P.V.; writing—review and editing, P.V., G.G. and F.B.; supervision, P.V. and F.B.

Conflicts of Interest: The authors have no conflict of interest to disclose in any of the products cited in the manuscript.

\section{References}

1. Craig, J.P.; Nichols, K.K.; Akpek, E.K.; Caffery, B.; Dua, H.S.; Joo, C.K.; Liu, Z.; Nelson, J.D.; Nichols, J.J.; Tsubota, K.; et al. TFOS DEWS II definition and classification report. Ocul. Surf. 2017, 15, 276-283. [CrossRef] [PubMed]

2. Stapleton, F.; Alves, M.; Bunya, V.Y.; Jalbert, I.; Lekhanont, K.; Malet, F.; Na, K.S.; Schaumberg, D.; Uchino, M.; Vehof, J.; et al. TFOS DEWS II epidemiology report. Ocul. Surf. 2017, 15, 334-365. [CrossRef] [PubMed]

3. Craig, J.P.; Nelson, J.D.; Azar, D.T.; Belmonte, C.; Bron, A.J.; Chauhan, S.K.; de Paiva, C.S.; Gomes, J.A.P.; Hammitt, K.M.; Jones, L.; et al. TFOS DEWS II report executive summary. Ocul. Surf. 2017, 15, 802-812. [CrossRef] [PubMed]

4. Benítez-Del-Castillo, J.; Labetoulle, M.; Baudouin, C.; Rolando, M.; Akova, Y.A.; Aragona, P.; Geerling, G.; Merayo-Lloves, J.; Messmer, E.M.; Boboridis, K. Visual acuity and quality of life in dry eye disease: Proceedings of the OCEAN group meeting. Ocul. Surf. 2017, 15, 169-178. [CrossRef] [PubMed]

5. Jones, L.; Downie, L.E.; Korb, D.; Benitez-Del-Castillo, J.M.; Dana, R.; Deng, S.X.; Dong, P.N.; Geerling, G.; Hida, R.Y.; Liu, Y.; et al. TFOS DEWS II management and therapy report. Ocul. Surf. 2017, 15, 575-628. [CrossRef] [PubMed]

6. Ralph, R.A.; Doane, M.G.; Dohlman, C.H. Clinical experience with a mobile ocular perfusion pump. Arch. Ophthalmol. 1975, 93, 1039-1043. [CrossRef] [PubMed]

7. Fox, R.I.; Chan, R.; Michelson, J.B.; Belmont, J.B.; Michelson, P.E. Beneficial effect of artificial tears made with autologous serum in patients with keratoconjunctivitis sicca. Arthritis Rheum. 1984, 27, 459-461. [CrossRef] [PubMed]

8. Soni, N.G.; Jeng, B.H. Blood-derived topical therapy for ocular surface diseases. Br. J. Ophthalmol. 2016, 100, 22-27. [CrossRef]

9. Giannaccare, G.; Versura, P.; Buzzi, M.; Primavera, L.; Pellegrini, M.; Campos, E.C. Blood derived eye drops for the treatment of cornea and ocular surface diseases. Transfus. Apher. Sci. 2017, 56, 595-604. [CrossRef]

10. Kojima, T.; Higuchi, A.; Goto, E.; Matsumoto, Y.; Dogru, M.; Tsubota, K. Autologous serum eye drops for the treatment of dry eye diseases. Cornea 2008, 27, S25-S30. [CrossRef] 
11. Tsubota, K.; Goto, E.; Shimmura, S.; Shimazaki, J. Treatment of persistent corneal epithelial defect by autologous serum application. Ophthalmology 1999, 106, 1984-1989. [CrossRef]

12. Freire, V.; Andollo, N.; Etxebarria, J.; Durán, J.A.; Morales, M.-C. In vitro effects of three blood derivatives on human corneal epithelial cells. Invest. Ophthalmol. Vis. Sci. 2012, 53, 5571-5578. [CrossRef] [PubMed]

13. Liu, L.; Hartwig, D.; Harloff, S.; Herminghaus, P.; Wedel, T.; Kasper, K.; Geerling, G. Corneal epitheliotrophic capacity of three different blood-derived preparations. Invest. Ophthalmol. Vis. Sci. 2006, 47, 2438-2444. [CrossRef] [PubMed]

14. Huang, C.-J.; Sun, Y.-C.; Christopher, K.; Pai, A.S.-I.; Lu, C.-J.; Hu, F.-R.; Lin, S.-Y.; Chen, W.-L. Comparison of corneal epitheliotrophic capacities among human platelet lysates and other blood derivatives. PLOS ONE 2017, 12, e0171008. [CrossRef] [PubMed]

15. Gipson, I.K. The ocular surface: The challenge to enable and protect vision: The Friedenwald lecture. Invest. Ophthalmol. Vis. Sci. 2007, 48, 4391-4398. [CrossRef] [PubMed]

16. Funderburgh, J.L.; Funderburgh, M.L.; Du, Y. Stem cells in the limbal stroma. Ocul. Surf. 2016, 14, 113-120. [CrossRef] [PubMed]

17. Geerling, G.; Maclennan, S.; Hartwig, D. Autologous serum eye drops for ocular surface disorders. Br. J. Ophthalmol. 2004, 88, 1467-1474. [CrossRef]

18. Higuchi, A. Autologous serum and serum components. Invest. Ophthalmol. Vis. Sci. 2018, 59, DES121-DES129. [CrossRef]

19. Drew, V.J.; Tseng, C.-L.; Seghatchian, J.; Burnouf, T. Reflections on dry eye syndrome treatment: Therapeutic role of blood products. Front. Med. 2018, 5, 33. [CrossRef]

20. Klenkler, B.; Sheardown, H.; Jones, L. Growth factors in the tear film: Role in tissue maintenance, wound healing, and ocular pathology. Ocul. Surf. 2007, 5, 228-239. [CrossRef]

21. Mandić, J.J.; Kozmar, A.; Kusačić-Kuna, S.; Jazbec, A.; Mandić, K.; Mrazovac, D.; Vukojević, N. The levels of 12 cytokines and growth factors in tears: Hyperthyreosis vs euthyreosis. Graefes Arch. Clin. Exp. Ophthalmol. 2018, 256, 845-852. [CrossRef] [PubMed]

22. Nurden, A.T. The biology of the platelet with special reference to inflammation, wound healing and immunity. Front. Biosci. 2018, 23, 726-751. [CrossRef]

23. Imanishi, J.; Kamiyama, K.; Iguchi, I.; Kita, M.; Sotozono, C.; Kinoshita, S. Growth factors: Importance in wound healing and maintenance of transparency of the cornea. Prog. Retin. Eye Res. 2000, 19, 113-129. [CrossRef]

24. Trosan, P.; Svobodova, E.; Chudickova, M.; Krulova, M.; Zajicova, A.; Holan, V. The key role of insulin-like growth factor I in limbal stem cell differentiation and the corneal wound-healing process. Stem Cells Dev. 2012, 21, 3341-3350. [CrossRef] [PubMed]

25. Ljubimov, A.V.; Saghizadeh, M. Progress in corneal wound healing. Prog. Retin. Eye Res. 2015, 49, 17-45. [CrossRef] [PubMed]

26. Liu, C.-Y.; Kao, W.W.-Y. Corneal epithelial wound healing. Prog. Mol. Biol. Transl. Sci. 2015, 134, 61-71. [PubMed]

27. Hongo, M.; Itoi, M.; Yamaguchi, N.; Imanishi, J. Distribution of epidermal growth factor (EGF) receptors in rabbit corneal epithelial cells, keratocytes and endothelial cells, and the changes induced by transforming growth factor- $\beta 1$. Exp. Eye Res. 1992, 54, 9-16. [CrossRef]

28. Aprili, G.; Gandini, G.; Guaschino, R.; Mazzucco, L.; Salvaneschi, L.; Vaglio, S. SIMTI recommendations on blood components for non-transfusional use. Blood Transfus. 2013, 11, 611-622.

29. About Preferred Practice Patterns (PPPs) - American Academy of Ophthalmology. Available online: https://www.aao.org/about-preferred-practice-patterns (accessed on 2 August 2019).

30. Marks, D.C.; van der Meer, P.F. Biomedical Excellence for Safer Transfusion (BEST) collaborative serum eye drops: A survey of international production methods. Vox Sang. 2017, 112, 310-317. [CrossRef]

31. Liu, L.; Hartwig, D.; Harloff, S.; Herminghaus, P.; Wedel, T.; Geerling, G. An optimised protocol for the production of autologous serum eyedrops. Graefes Arch. Clin. Exp. Ophthalmol. 2005, 243, 706-714. [CrossRef]

32. Pancholi, S.; Tullo, A.; Khaliq, A.; Foreman, D.; Boulton, M. The effects of growth factors and conditioned media on the proliferation of human corneal epithelial cells and keratocytes. Graefes Arch. Clin. Exp. Ophthalmol. 1998, 236, 1-8. [CrossRef]

33. Torricelli, A.A.M.; Santhanam, A.; Wu, J.; Singh, V.; Wilson, S.E. The corneal fibrosis response to epithelial-stromal injury. Exp. Eye Res. 2016, 142, 110-118. [CrossRef] [PubMed] 
34. Pan, Q.; Angelina, A.; Marrone, M.; Stark, W.J.; Akpek, E.K. Autologous serum eye drops for dry eye. Cochrane Database Syst. Rev. 2017, 2, CD009327. [CrossRef] [PubMed]

35. Jeng, B.H.; Dupps, W.J. Autologous serum 50\% eyedrops in the treatment of persistent corneal epithelial defects. Cornea 2009, 28, 1104-1108. [CrossRef] [PubMed]

36. Lekhanont, K.; Jongkhajornpong, P.; Anothaisintawee, T.; Chuckpaiwong, V. Undiluted serum eye drops for the treatment of persistent corneal epitheilal defects. Sci. Rep. 2016, 6, 38143. [CrossRef] [PubMed]

37. Cho, Y.K.; Huang, W.; Kim, G.Y.; Lim, B.S. Comparison of autologous serum eye drops with different diluents. Curr. Eye Res. 2013, 38, 9-17. [CrossRef]

38. Hussain, M.; Shtein, R.M.; Sugar, A.; Soong, H.K.; Woodward, M.A.; DeLoss, K.; Mian, S.I. Long-term use of autologous serum $50 \%$ eye drops for the treatment of dry eye disease. Cornea 2014, 33, 1245-1251. [CrossRef]

39. López-García, J.S.; García-Lozano, I.; Rivas, L.; Ramírez, N.; Raposo, R.; Méndez, M.T. Autologous serum eye drops diluted with sodium hyaluronate: Clinical and experimental comparative study. Acta Ophthalmol. 2014, 92, e22-e29. [CrossRef]

40. Bradley, J.C.; Simoni, J.; Bradley, R.H.; McCartney, D.L.; Brown, S.M. Time-and temperature-dependent stability of growth factor peptides in human autologous serum eye drops. Cornea 2009, 28, 200-205. [CrossRef]

41. Tsubota, K.; Goto, E.; Fujita, H.; Ono, M.; Inoue, H.; Saito, I.; Shimmura, S. Treatment of dry eye by autologous serum application in Sjögren's syndrome. Br. J. Ophthalmol. 1999, 83, 390-395. [CrossRef]

42. Fischer, K.R.; Opitz, A.; Böeck, M.; Geerling, G. Stability of serum eye drops after storage of 6 months. Cornea 2012, 31, 1313-1318. [CrossRef] [PubMed]

43. WHO. Expert Committee on Specifications for Pharmaceutical Preparations; World Health Organization: Geneva, Switzerland, 2011; pp. 1-428.

44. Marchand, M.; Harissi-Dagher, M.; Germain, M.; Thompson, P.; Robert, M.-C. Serum drops for ocular surface disease: National survey of Canadian cornea specialists. Can. J. Ophthalmol. 2018, 53, 266-271. [CrossRef] [PubMed]

45. Tahmaz, V.; Gehlsen, U.; Sauerbier, L.; Holtick, U.; Engel, L.; Radojska, S.; Petrescu-Jipa, V.-M.; Scheid, C.; Hallek, M.; Gathof, B.; et al. Treatment of severe chronic ocular graft-versus-host disease using $100 \%$ autologous serum eye drops from a sealed manufacturing system: A retrospective cohort study. Br. J. Ophthalmol. 2017, 101, 322-326. [CrossRef] [PubMed]

46. Versura, P.; Profazio, V.; Buzzi, M.; Stancari, A.; Arpinati, M.; Malavolta, N.; Campos, E.C. Efficacy of standardized and quality-controlled cord blood serum eye drop therapy in the healing of severe corneal epithelial damage in dry eye. Cornea 2013, 32, 412-418. [CrossRef] [PubMed]

47. Marks, D.C.; Fisher, J.; Mondy, P.; Segatchian, J.; Dennington, P.M. Serum eye drop preparation in Australia: Current manufacturing practice. Transfus. Apher. Sci. 2015, 53, 92-94. [CrossRef] [PubMed]

48. Spaniol, K.; Koerschgen, L.; Sander, O.; Koegler, G.; Geerling, G. Comparison of application systems for autologous serum eye drops. Curr. Eye Res. 2014, 39, 571-579. [CrossRef] [PubMed]

49. Tananuvat, N.; Daniell, M.; Sullivan, L.J.; Yi, Q.; McKelvie, P.; McCarty, D.J.; Taylor, H.R. Controlled study of the use of autologous serum in dry eye patients. Cornea 2001, 20, 802-806. [CrossRef] [PubMed]

50. Noble, B.A.; Loh, R.S.K.; MacLennan, S.; Pesudovs, K.; Reynolds, A.; Bridges, L.R.; Burr, J.; Stewart, O.; Quereshi, S. Comparison of autologous serum eye drops with conventional therapy in a randomised controlled crossover trial for ocular surface disease. Br. J. Ophthalmol. 2004, 88, 647-652. [CrossRef] [PubMed]

51. Kojima, T.; Ishida, R.; Dogru, M.; Goto, E.; Matsumoto, Y.; Kaido, M.; Tsubota, K. The effect of autologous serum eyedrops in the treatment of severe dry eye disease: A prospective randomized case-control study. Am. J. Ophthalmol. 2005, 139, 242-246. [CrossRef]

52. Urzua, C.A.; Vasquez, D.H.; Huidobro, A.; Hernandez, H.; Alfaro, J. Randomized double-blind clinical trial of autologous serum versus artificial tears in dry eye syndrome. Curr. Eye Res. 2012, 37, 684-688. [CrossRef]

53. Celebi, A.R.C.; Ulusoy, C.; Mirza, G.E. The efficacy of autologous serum eye drops for severe dry eye syndrome: A randomized double-blind crossover study. Graefes Arch. Clin. Exp. Ophthalmol. 2014, 252, 619-626. [CrossRef] [PubMed]

54. Yılmaz, U.; Küçük, E.; Koç, Ç.; Gökler, E. Comparison of autologous serum versus preservative free artificial tear in patients with dry eyes due to systemic isotretinoin therapy. Curr. Eye Res. 2017, 42, 827-831. [CrossRef] [PubMed] 
55. Ogawa, Y.; Okamoto, S.; Mori, T.; Yamada, M.; Mashima, Y.; Watanabe, R.; Kuwana, M.; Tsubota, K.; Ikeda, Y.; Oguchi, Y. Autologous serum eye drops for the treatment of severe dry eye in patients with chronic graft-versus-host disease. Bone Marrow Transpl. 2003, 31, 579-583. [CrossRef] [PubMed]

56. Hwang, J.; Chung, S.-H.; Jeon, S.; Kwok, S.-K.; Park, S.-H.; Kim, M.-S. Comparison of clinical efficacies of autologous serum eye drops in patients with primary and secondary Sjögren syndrome. Cornea 2014, 33, 663-667. [CrossRef] [PubMed]

57. Semeraro, F.; Forbice, E.; Nascimbeni, G.; Taglietti, M.; Romano, V.; Guerra, G.; Costagliola, C. Effect of autologous serum eye drops in patients with Sjögren syndrome-related dry eye: Clinical and in vivo confocal microscopy evaluation of the ocular surface. In Vivo 2016, 30, 931-938. [CrossRef] [PubMed]

58. Jirsova, K.; Brejchova, K.; Krabcova, I.; Filipec, M.; Al Fakih, A.; Palos, M.; Vesela, V. The application of autologous serum eye drops in severe dry eye patients; subjective and objective parameters before and after treatment. Curr. Eye Res. 2014, 39, 21-30. [CrossRef] [PubMed]

59. Matsumoto, Y.; Dogru, M.; Goto, E.; Ohashi, Y.; Kojima, T.; Ishida, R.; Tsubota, K. Autologous serum application in the treatment of neurotrophic keratopathy. Ophthalmology 2004, 111, 1115-1120. [CrossRef] [PubMed]

60. Noda-Tsuruya, T.; Asano-Kato, N.; Toda, I.; Tsubota, K. Autologous serum eye drops for dry eye after LASIK. J. Refract. Surg. 2006, 22, 61-66. [CrossRef] [PubMed]

61. Schulze, S.D.; Sekundo, W.; Kroll, P. Autologous serum for the treatment of corneal epithelial abrasions in diabetic patients undergoing vitrectomy. Am. J. Ophthalmol. 2006, 142, 207-211. [CrossRef] [PubMed]

62. Ziakas, N.G.; Boboridis, K.G.; Terzidou, C.; Naoumidi, T.L.; Mikropoulos, D.; Georgiadou, E.N.; Georgiadis, N.S. Long-term follow up of autologous serum treatment for recurrent corneal erosions. Clin. Exp. Ophthalmol. 2010, 38, 683-687. [CrossRef]

63. Lekhanont, K.; Jongkhajornpong, P.; Choubtum, L.; Chuckpaiwong, V. Topical 100\% serum eye drops for treating corneal epithelial defect after ocular surgery. Biomed. Res. Int. 2013, 2013, 521315. [CrossRef] [PubMed]

64. Sul, S.; Korkmaz, S.; Alacamli, G.; Ozyol, P.; Ozyol, E. Application of autologous serum eye drops after pterygium surgery: A prospective study. Graefes Arch. Clin. Exp. Ophthalmol. 2018, 256, 1939-1943. [CrossRef] [PubMed]

65. Chen, Y.-M.; Hu, F.-R.; Huang, J.-Y.; Shen, E.P.; Tsai, T.-Y.; Chen, W.-L. The effect of topical autologous serum on graft re-epithelialization after penetrating keratoplasty. Am. J. Ophthalmol. 2010, 150, 352-359.e2. [CrossRef] [PubMed]

66. López-García, J.S.; Rivas, L.; García-Lozano, I.; Murube, J. Autologous serum eyedrops in the treatment of aniridic keratopathy. Ophthalmology 2008, 115, 262-267. [CrossRef] [PubMed]

67. Espinosa, A.; Hjorth-Hansen, H.; Aasly, K.; Teigum, I.; Sivertsen, G.; Seghatchian, J. Implementation of a standardised method for the production of allogeneic serum eye drops from regular blood donors in a Norwegian University Hospital: Some methodological aspects and clinical considerations. Transfus. Apher. Sci. 2015, 53, 88-91. [CrossRef] [PubMed]

68. Badami, K.G.; McKellar, M. Allogeneic serum eye drops: Time these became the norm? Br. J. Ophthalmol. 2012, 96, 1151-1152. [CrossRef]

69. Chiang, C.-C.; Chen, W.-L.; Lin, J.-M.; Tsai, Y.-Y. Allogeneic serum eye drops for the treatment of persistent corneal epithelial defect. Eye 2009, 23, 290-293. [CrossRef]

70. Chiang, C.-C.; Lin, J.-M.; Chen, W.-L.; Tsai, Y.-Y. Allogeneic serum eye drops for the treatment of severe dry eye in patients with chronic graft-versus-host disease. Cornea 2007, 26, 861-863. [CrossRef]

71. Harritshøj, L.H.; Nielsen, C.; Ullum, H.; Hansen, M.B.; Julian, H.O. Ready-made allogeneic ABO-specific serum eye drops: Production from regular male blood donors, clinical routine, safety and efficacy. Acta Ophthalmol. 2014, 92, 783-786. [CrossRef]

72. Na, K.-S.; Kim, M.S. Allogeneic serum eye drops for the treatment of dry eye patients with chronic graft-versus-host disease. J. Ocul. Pharmacol. Ther. 2012, 28, 479-483. [CrossRef]

73. Anitua, E.; de la Fuente, M.; Merayo-Lloves, J.; Muruzabal, F.; Orive, G. Allogeneic blood-based therapies: Hype or hope? Eye 2017, 31, 509-510. [CrossRef] [PubMed]

74. Hung, Y.; Elder, M.J.; Rawstron, J.A.; Badami, K.G. A retrospective crossover study of autologous and allogeneic serum eye drops for the management of ocular surface disease. Transfus. Med. 2019, 29, 69-71. [CrossRef] 
75. Van der Meer, P.F.; Seghatchian, J.; de Korte, D. Autologous and allogeneic serum eye drops. The Dutch perspective. Transfus. Apher. Sci. 2015, 53, 99-100. [CrossRef] [PubMed]

76. Stenwall, P.-A.; Bergström, M.; Seiron, P.; Sellberg, F.; Olsson, T.; Knutson, F.; Berglund, D. Improving the anti-inflammatory effect of serum eye drops using allogeneic serum permissive for regulatory $\mathrm{T}$ cell induction. Acta Ophthalmol. 2015, 93, 654-657. [CrossRef] [PubMed]

77. Kang, N.H.; Lee, S.; Jun, R.M. Comparison of epitheliotrophic factors in autologous serum eyedrops from sera of chronic renal failure patients vs. normal controls. Graefes Arch. Clin. Exp. Ophthalmol. 2015, 253, 1705-1712. [CrossRef] [PubMed]

78. Harloff, S.; Hartwig, D.; Kasper, K.; Wedel, T.; Müller, M.; Geerling, G. Epitheliotrophic capacity of serum eye drops from healthy donors versus serum from immunosuppressed patients with rheumatoid arthritis. Klin. Monbl. Augenheilkd. 2008, 225, 200-206. [CrossRef]

79. WHO. Expert Committee on Biological Standardization; World Health Organization: Geneva, Switzerland, 2007; pp. 1-340.

80. Scharman, C.D.; Burger, D.; Shatzel, J.J.; Kim, E.; DeLoughery, T.G. Treatment of individuals who cannot receive blood products for religious or other reasons. Am. J. Hematol. 2017, 92, 1370-1381. [CrossRef]

81. Giannaccare, G.; Pellegrini, M.; Bernabei, F.; Moscardelli, F.; Buzzi, M.; Versura, P.; Campos, E.C. In vivo confocal microscopy automated morphometric analysis of corneal subbasal nerve plexus in patients with dry eye treated with different sources of homologous serum eye drops. Cornea 2019. [CrossRef]

82. Yoon, K.-C.; Im, S.-K.; Park, Y.-G.; Jung, Y.-D.; Yang, S.-Y.; Choi, J. Application of umbilical cord serum eyedrops for the treatment of dry eye syndrome. Cornea 2006, 25, 268-272. [CrossRef]

83. Versura, P.; Buzzi, M.; Giannaccare, G.; Terzi, A.; Fresina, M.; Velati, C.; Campos, E.C. Targeting growth factor supply in keratopathy treatment: Comparison between maternal peripheral blood and cord blood as sources for the preparation of topical eye drops. Blood Transfus. 2016, 14, 145-151.

84. Buzzi, M.; Versura, P.; Grigolo, B.; Cavallo, C.; Terzi, A.; Pellegrini, M.; Giannaccare, G.; Randi, V.; Campos, E.C. Comparison of growth factor and interleukin content of adult peripheral blood and cord blood serum eye drops for cornea and ocular surface diseases. Transfus. Apher. Sci. 2018, 57, 549-555. [CrossRef] [PubMed]

85. Versura, P.; Buzzi, M.; Giannaccare, G.; Grillini, M.; Terzi, A.; Pagliaro, P.; Campos, E.C. Cord blood serum-based eye drops; the impact of donor haematological and obstetric factors on the variability of epidermal growth factor levels. Blood Transfus. 2014, 12 (Suppl. S1), 44-50.

86. Giannaccare, G.; Buzzi, M.; Fresina, M.; Velati, C.; Versura, P. Efficacy of 2-month treatment with cord blood serum eye drops in ocular surface disease: An in vivo confocal microscopy study. Cornea 2017, 36, $915-921$. [CrossRef] [PubMed]

87. Erdem, E.; Yagmur, M.; Harbiyeli, I.; Taylan-Sekeroglu, H.; Ersoz, R. Umbilical cord blood serum therapy for the management of persistent corneal epithelial defects. Int. J. Ophthalmol. 2014, 7, 807-810.

88. Vajpayee, R.B.; Mukerji, N.; Tandon, R.; Sharma, N.; Pandey, R.M.; Biswas, N.R.; Malhotra, N.; Melki, S.A. Evaluation of umbilical cord serum therapy for persistent corneal epithelial defects. Br. J. Ophthalmol. 2003, 87, 1312-1316. [CrossRef]

89. Yoon, K.-C.; Heo, H.; Jeong, I.-Y.; Park, Y.-G. Therapeutic effect of umbilical cord serum eyedrops for persistent corneal epithelial defect. Korean J. Ophthalmol. 2005, 19, 174-178. [CrossRef]

90. Yoon, K.-C.; Heo, H.; Im, S.-K.; You, I.-C.; Kim, Y.-H.; Park, Y.-G. Comparison of autologous serum and umbilical cord serum eye drops for dry eye syndrome. Am. J. Ophthalmol. 2007, 144, 86-92. [CrossRef]

91. Sharma, N.; Goel, M.; Velpandian, T.; Titiyal, J.S.; Tandon, R.; Vajpayee, R.B. Evaluation of umbilical cord serum therapy in acute ocular chemical burns. Invest. Ophthalmol. Vis. Sci. 2011, 52, 1087-1092. [CrossRef]

92. Sharma, N.; Singh, D.; Maharana, P.K.; Kriplani, A.; Velpandian, T.; Pandey, R.M.; Vajpayee, R.B. Comparison of amniotic membrane transplantation and umbilical cord serum in acute ocular chemical burns: A randomized controlled trial. Am. J. Ophthalmol. 2016, 168, 157-163. [CrossRef]

93. Yoon, K.C.; Jeong, I.Y.; Im, S.K.; Park, Y.G.; Kim, H.J.; Choi, J. Therapeutic effect of umbilical cord serum eyedrops for the treatment of dry eye associated with graft-versus-host disease. Bone Marrow Transpl. 2007, 39, 231-235. [CrossRef]

94. Yoon, K.-C.; Choi, W.; You, I.-C.; Choi, J. Application of umbilical cord serum eyedrops for recurrent corneal erosions. Cornea 2011, 30, 744-748. [CrossRef] 
95. Kamble, N.; Sharma, N.; Maharana, P.K.; Bandivadekar, P.; Nagpal, R.; Agarwal, T.; Velpandian, T.; Mittal, S.; Vajpayee, R.B. Evaluation of the role of umbilical cord serum and autologous serum therapy in reepithelialization after keratoplasty: A randomized controlled clinical trial. Eye Contact Lens 2017, 43, 324-329. [CrossRef] [PubMed]

96. Yoon, K.-C.; Oh, H.-J.; Park, J.-W.; Choi, J. Application of umbilical cord serum eyedrops after laser epithelial keratomileusis. Acta Ophthalmol. 2013, 91, e22-e28. [CrossRef] [PubMed]

97. Mukhopadhyay, S.; Sen, S.; Datta, H. Comparative role of $20 \%$ cord blood serum and $20 \%$ autologous serum in dry eye associated with Hansen's disease: A tear proteomic study. Br. J. Ophthalmol. 2015, 99, 108-112. [CrossRef] [PubMed]

98. Yoon, K.-C.; You, I.-C.; Im, S.-K.; Jeong, T.-S.; Park, Y.-G.; Choi, J. Application of umbilical cord serum eyedrops for the treatment of neurotrophic keratitis. Ophthalmology 2007, 114, 1637-1642. [CrossRef] [PubMed]

99. Versura, P.; Giannaccare, G.; Pellegrini, M.; Sebastiani, S.; Campos, E.C. Neurotrophic keratitis: Current challenges and future prospects. Eye Brain 2018, 10, 37-45. [CrossRef] [PubMed]

100. Lubkowska, A.; Dolegowska, B.; Banfi, G. Growth factor content in PRP and their applicability in medicine. J. Biol. Regul. Homeost. Agents 2012, 26, 3S-22S. [PubMed]

101. Alio, J.L.; Arnalich-Montiel, F.; Rodriguez, A.E. The role of "eye platelet rich plasma" (E-PRP) for wound healing in ophthalmology. Curr. Pharm. Biotechnol. 2012, 13, 1257-1265. [CrossRef]

102. Sanchez-Avila, R.M.; Merayo-Lloves, J.; Riestra, A.C.; Anitua, E.; Muruzabal, F.; Orive, G.; Fernández-Vega, L. The effect of immunologically safe plasma rich in growth factor eye drops in patients with Sjögren syndrome. J. Ocul. Pharm. 2017, 33, 391-399. [CrossRef] [PubMed]

103. Pezzotta, S.; Del Fante, C.; Scudeller, L.; Rossi, G.C.; Perotti, C.; Bianchi, P.E.; Antoniazzi, E. Long-term safety and efficacy of autologous platelet lysate drops for treatment of ocular GvHD. Bone Marrow Transpl. 2017, 52, 101-106. [CrossRef] [PubMed]

104. Zallio, F.; Mazzucco, L.; Monaco, F.; Astori, M.R.; Passera, R.; Drago, G.; Tamiazzo, S.; Rapetti, M.; Dolcino, D.; Guaschino, R.; et al. A single-center pilot prospective study of topical application of platelet-derived eye drops for patients with ocular chronic graft-versus-host disease. Biol. Blood Marrow Transpl. 2016, 22, 1664-1670. [CrossRef] [PubMed]

105. Alio, J.L.; Colecha, J.R.; Pastor, S.; Rodriguez, A.; Artola, A. Symptomatic dry eye treatment with autologous platelet-rich plasma. Ophthalmic Res. 2007, 39, 124-129. [CrossRef] [PubMed]

106. Alio, J.L.; Pastor, S.; Ruiz-Colecha, J.; Rodriguez, A.; Artola, A. Treatment of ocular surface syndrome after LASIK with autologous platelet-rich plasma. J. Refract. Surg. 2007, 23, 617-619. [CrossRef] [PubMed]

107. Alio, J.L.; Abad, M.; Artola, A.; Rodriguez-Prats, J.L.; Pastor, S.; Ruiz-Colecha, J. Use of autologous platelet-rich plasma in the treatment of dormant corneal ulcers. Ophthalmology 2007, 114, 1286-1293.e1. [CrossRef] [PubMed]

108. López-Plandolit, S.; Morales, M.-C.; Freire, V.; Etxebarría, J.; Durán, J.A. Plasma rich in growth factors as a therapeutic agent for persistent corneal epithelial defects. Cornea 2010, 29, 843-848. [CrossRef] [PubMed]

109. Pezzotta, S.; Del Fante, C.; Scudeller, L.; Cervio, M.; Antoniazzi, E.R.; Perotti, C. Autologous platelet lysate for treatment of refractory ocular GVHD. Bone Marrow Transpl. 2012, 47, 1558-1563. [CrossRef] [PubMed]

110. Kim, K.M.; Shin, Y.-T.; Kim, H.K. Effect of autologous platelet-rich plasma on persistent corneal epithelial defect after infectious keratitis. Jpn. J. Ophthalmol. 2012, 56, 544-550. [CrossRef]

111. Panda, A.; Jain, M.; Vanathi, M.; Velpandian, T.; Khokhar, S.; Dada, T. Topical autologous platelet-rich plasma eyedrops for acute corneal chemical injury. Cornea 2012, 31, 989-993. [CrossRef]

112. Fea, A.M.; Aragno, V.; Testa, V.; Machetta, F.; Parisi, S.; D’Antico, S.; Spinetta, R.; Fusaro, E.; Grignolo, F.M. The effect of autologous platelet lysate eye drops: An in vivo confocal microscopy study. Biomed. Res. Int. 2016, 2016, 8406832. [CrossRef]

113. Lee, J.H.; Kim, M.J.; Ha, S.W.; Kim, H.K. Autologous platelet-rich plasma eye drops in the treatment of recurrent corneal erosions. Korean J. Ophthalmol. 2016, 30, 101-107. [CrossRef]

114. Merayo-Lloves, J.; Sanchez-Avila, R.M.; Riestra, A.C.; Anitua, E.; Begoña, L.; Orive, G.; Fernandez-Vega, L. Safety and efficacy of autologous plasma rich in growth factors eye drops for the treatment of evaporative dry eye. Ophthalmic Res. 2016, 56, 68-73. [CrossRef] [PubMed]

115. Sanchez-Avila, R.M.; Merayo-Lloves, J.; Riestra, A.C.; Fernandez-Vega Cueto, L.; Anitua, E.; Begoña, L.; Muruzabal, F.; Orive, G. Treatment of patients with neurotrophic keratitis stages 2 and 3 with plasma rich in growth factors (PRGF-Endoret) eye-drops. Int. Ophthalmol. 2018, 38, 1193-1204. [CrossRef] [PubMed] 
116. Sanchez-Avila, R.M.; Merayo-Lloves, J.; Fernandez,M.L.; Rodriguez-Gutierrez, L.A.; Jurado, N.; Muruzabal, F.; Orive, G.; Anitua, E. Plasma rich in growth factors for the treatment of dry eye after LASIK surgery. Ophthalmic Res. 2018, 60, 80-86. [CrossRef]

117. Sanchez-Avila, R.M.; Merayo-Lloves, J.; Muruzabal, F.; Orive, G.; Anitua, E. Plasma rich in growth factors for the treatment of dry eye from patients with graft versus host diseases. Eur. J. Ophthalmol. 2018, 1120672118818943. [CrossRef] [PubMed]

118. Wróbel-Dudzińska, D.; Alio, J.; Rodriguez, A.; Suchodoła-Ratajewicz, E.; Kosior-Jarecka, E.; Rymgayłło-Jankowska, B.; Ćwiklińska-Haszcz, A.; Żarnowski, T. Clinical efficacy of platelet-rich plasma in the treatment of neurotrophic corneal ulcer. J. Ophthalmol. 2018, 2018, 3538764. [CrossRef] [PubMed]

119. García-Conca, V.; Abad-Collado, M.; Hueso-Abancens, J.R.; Mengual-Verdú, E.; Piñero, D.P.; Aguirre-Balsalobre, F.; Molina, J.C. Efficacy and safety of treatment of hyposecretory dry eye with platelet-rich plasma. Acta Ophthalmol. 2019, 97, e170-e178.

120. Alio, J.L.; Rodriguez, A.E.; Martinez, L.M.; Rio, A.L. Autologous fibrin membrane combined with solid platelet-rich plasma in the management of perforated corneal ulcers: A pilot study. JAMA Ophthalmol. 2013, 131, 745-751. [CrossRef]

121. Avila, M.Y.; Igua, A.M.; Mora, A.M. Randomised, prospective clinical trial of platelet-rich plasma injection in the management of severe dry eye. Br. J. Ophthalmol. 2019, 103, 648-653. [CrossRef]

122. Rauz, S.; Koay, S.-Y.; Foot, B.; Kaye, S.B.; Figueiredo, F.; Burdon, M.A.; Dancey, E.; Chandrasekar, A.; Lomas, R. The royal college of ophthalmologists guidelines on serum eye drops for the treatment of severe ocular surface disease: Full report. Eye 2017. [CrossRef]

123. Rauz, S.; Koay, S.-Y.; Foot, B.; Kaye, S.B.; Figueiredo, F.; Burdon, M.A.; Dancey, E.; Chandrasekar, A.; Lomas, R. The royal college of ophthalmologists guidelines on serum eye drops for the treatment of severe ocular surface disease: Executive summary. Eye 2018, 32, 44-48. [CrossRef]

124. Akeda, K.; Yamada, J.; Linn, E.T.; Sudo, A.; Masuda, K. Platelet-rich plasma in the management of chronic low back pain: A critical review. J. Pain Res. 2019, 12, 753-767. [CrossRef] [PubMed]

(C) 2019 by the authors. Licensee MDPI, Basel, Switzerland. This article is an open access article distributed under the terms and conditions of the Creative Commons Attribution (CC BY) license (http://creativecommons.org/licenses/by/4.0/). 